\title{
CONCENTRATIONS OF DISSOLVED RADON-222 IN WATER FROM SELECTED WELLS AND SPRINGS IN IDAHO, 1989-91
}

By L. DeWayne Cecil, D.J. Parliman, Daniel D. Edwards, and H.W. Young

\section{U.S. GEOLOGICAL SURVEY}

Open-File Report 94-66

Prepared in cooperation with the IDAHO DEPARTMENT OF WATER RESOURCES

and the

U.S. DEPARTMENT OF ENERGY

Idaho Falls, Idaho

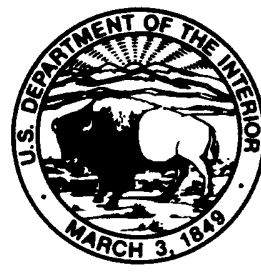




\section{U.S. DEPARTMENT OF THE INTERIOR \\ BRUCE BABBITT, Secretary}

\section{U.S. GEOLOGICAL SURVEY}

Robert M. Hirsch, Acting Director

Use of brand or firm names in this report is for identification purposes only and does not constitute endorsement by the U.S. Geological Survey, the Department of Energy, or the Idaho Department of Water Resources.

For additional information write to:

Project Chief

U.S. Geological Survey

INEL, MS 4148

P.O. Box 2230

Idaho Falls, ID 83403
Copies of this report can be purchased from:

U.S. Geological Survey

Earth Science Information Center

Open-File Report Section

Box 25286, Mail Stop 517

Federal Center

Denver, CO 80225 


\section{CONTENTS}

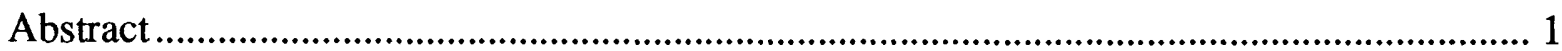

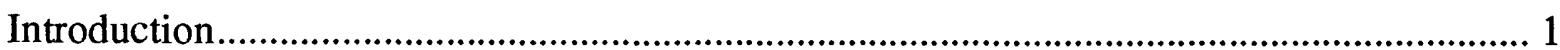

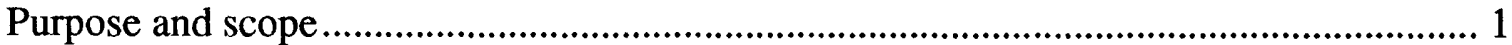

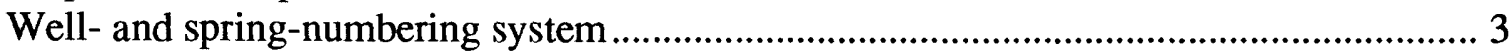

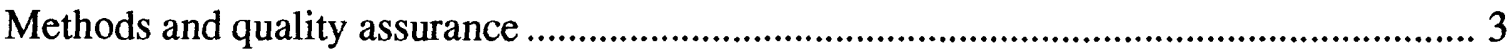

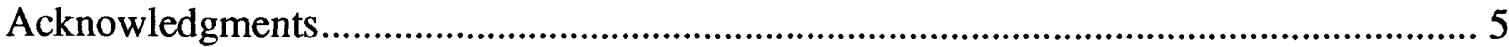

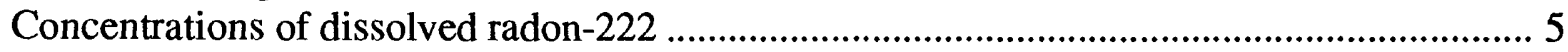

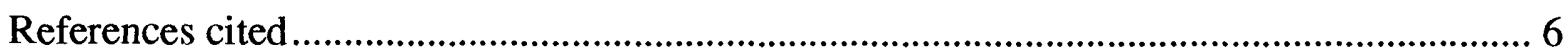

\section{FIGURES}

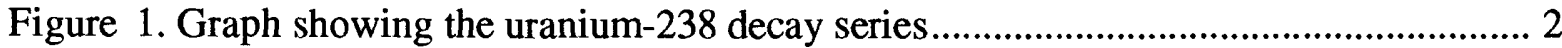

2. Diagram showing well- and spring-numbering system ........................................ 4

3-9. Maps showing:

3. Location of wells and springs sampled for radon in north Idaho ............................. 7

4. Location of wells and springs sampled for radon in north-central Idaho .................. 8

5. Location of wells and springs sampled for radon in west-central Idaho .....................9

6. Location of wells and springs sampled for radon in east-central Idaho ................. 10

7. Location of wells and springs sampled for radon in southwest Idaho.................... 11

8. Location of wells and springs sampled for radon in south-central Idaho ................ 12

9. Location of wells and springs sampled for radon in southeast Idaho .........................13

\section{TABLE}

Table 1. Concentrations of dissolved radon-222 in water from selected wells and springs in Idaho, 1989-91

CONVERSION FACTORS AND ABBREVIATED UNITS

\begin{tabular}{rll}
\hline Multiply & \multicolumn{1}{c}{ By } & To Obtain \\
\hline inch (in.) & 2.54 & centimeter \\
foot (ft) & 0.3048 & meter \\
mile (mi) & 1.609 & kilometer \\
acre & 0.4047 & hectare \\
picocurie per liter (pCi/L) & 0.037 & becquerel per liter \\
\hline
\end{tabular}

Temperature in ${ }^{\circ} \mathrm{C}$ (degrees Celsius) can be converted to ${ }^{\circ} \mathrm{F}$ (degrees Fahrenheit) as follows: ${ }^{\circ} \mathrm{F}=(1.8)\left({ }^{\circ} \mathrm{C}\right)+32$

Abbreviated units used in report: $\mathrm{cm}$ (centimeter); $\mathrm{mL}$ (milliliter) . 


\title{
CONCENTRATIONS OF DISSOLVED RADON-222 IN WATER FROM SELECTED WELLS AND SPRINGS IN IDAHO, 1989-91
}

\author{
By L. DeWayne Cecil, D.J. Parliman, Daniel D. Edwards and H.W. Young
}

\begin{abstract}
Concentrations of dissolved radon-222, a naturally occurring radioactive gas, are found in water in Idaho. The U.S. Geological Survey collected water samples for radon- 222 analyses from 338 Idaho wells and springs during 1989-91. These water samples were collected as part of ongoing monitoring programs with the Idaho Department of Water Resources and the U.S. Department of Energy. Concentrations of dissolved radon-222 in 372 of the water samples ranged from $-58 \pm 30$ to $5,715 \pm 66$ picocuries per liter; the mean and median concentrations were $446 \pm 35$ and $242 \pm 25$ picocuries per liter, respectively.
\end{abstract}

\section{INTRODUCTION}

Radon-222 is a naturally occurring radioactive gas that may be dissolved in water. Radon-222 concentrations in water from Idaho wells and springs are needed by Federal, State, and local agencies to characterize its distribution and to identify the lifetime risks related to exposure. The U.S. Environmental Protection Agency (EPA) estimated that between 2,000 and 40,000 excess lung cancer fatalities in the United States during any 70-year period (an average human life span) result from radon-222 released from public water supplies (Cothern, 1987). The average concentration of radon-222 in public water supplies in the United States generates a lifetime risk of death from lung cancer of 1 in 10,000, a risk larger than that generated by any contaminant currently regulated by the Safe Drinking Water Act. The EPA has proposed a maximum contaminant level of $300 \mathrm{pCi} / \mathrm{L}$ (picocuries per liter) for radon-222 dissolved in drinking water from public supply systems (EPA, 1991).

\section{Purpose and Scope}

The purpose of this report is to present the results of analyses for that fraction of radon-222 dissolved in water collected from 338 wells and springs in Idaho during 1989-91 by the U.S.

Geological Survey (USGS). The work was done in cooperation with the Idaho Department of Water Resources and the U.S. Department of Energy as part of ongoing water-quality monitoring programs throughout the State and in the vicinity of the Idaho National Engineering Laboratory.

Radon-222, traditionally called radon, is in the uranium-238 decay series (fig. 1) and has a halflife of 3.82 days; the half-life is the time necessary for one half of the atoms to radioactively decay. Radon isotopes with shorter half-lives include radon-220 (thoron) with a half-life of 55 seconds and radon-219 (actinon) with a half-life of 


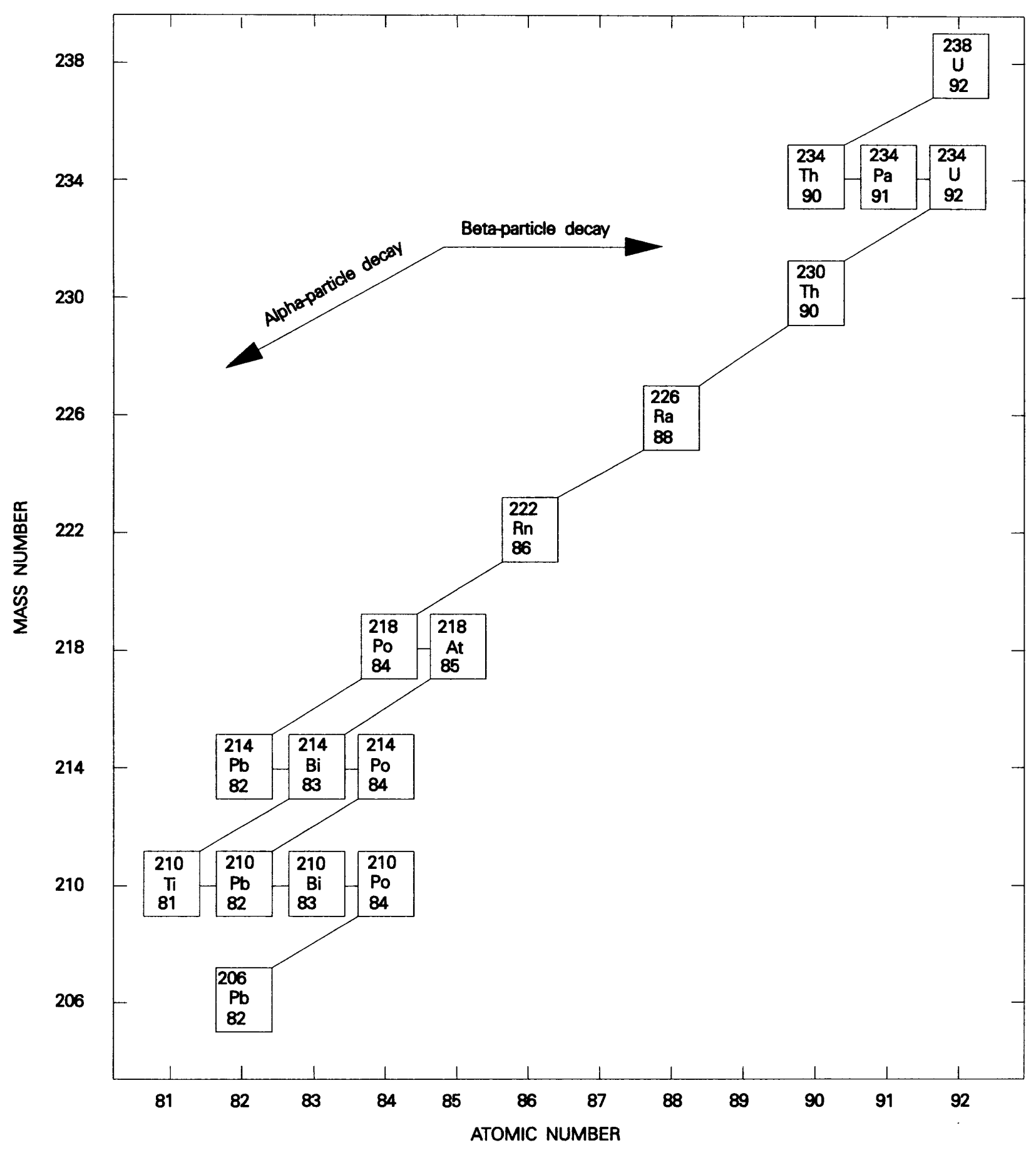

Figure 1.-The uranium-238 decay series. 
4 seconds. The concentrations presented in this report are for dissolved radon-222 as this is the only isotope of environmental concern due to its relatively long half-life as compared to radon-220 and radon-219.

\section{Well- And Spring-Numbering System}

The well and spring identifier (table 1) used by the USGS in Idaho indicates the location of wells or springs within the official rectangular subdivision of public lands, with reference to the Boise Base Line and Meridian. The first two segments of the number designate the township (T) north or south and range (R) east or west. The third segment gives the section number; four letters, which indicate the $1 / 4$ section (160-acre tract), 1/4-1/4 section (40 acre tract), 1/4-1/4-1/4 section (10 acre tract), 1/4-1/4-1/4-1/4 section (2 1/2-acre tract); and serial number of the well or spring within the tract.

Quarter sections are designated by the letters A, $B, C$, and D in counterclockwise order from the northeast quarter of each section. Forty-acre, 10-acre, and $21 / 2$-acre tracts within each quarter section are lettered in the same manner. Well $5 \mathrm{~N}-2 \mathrm{E}-29 \mathrm{BCC} 1$ (fig. 2 ) is in the southwest quarter of the southwest quarter of the northwest quarter of Section 29, T. 5 N., R. 2 E.; and was the first well inventoried in that tract. Springs are designated by the letter " $S$ " following the last number.

The USGS identification number used on table 1 consists of 15 digits and is unique to each site. Additionally, several springs listed on table 1 have an 8-digit downstream order number for identification rather than the 15-digit identification number. The 8-digit number is utilized for springs that discharge to rivers or streams and that are routinely sampled by the USGS. The 8-digit numbers for these springs, such as 13117391 , include a 2-digit part number "13" plus a 6-digit downstream order number "117391".

\section{Methods And Quality Assurance}

The methodology used to collect water samples from wells and springs for radon analyses generally followed guidelines established by the USGS (Wood, 1981; Claassen, 1982; and Cecil and Gesell, 1992). Equipment used to collect water from wells included a short, flexible piece of tubing inserted into a $1,000-\mathrm{mL}$ beaker, a $20-\mathrm{mL}$ glass or polyethylene hypodermic syringe with an 18-gage stainless steel hypodermic needle, and two glass scintillation vials per sampling site with $10 \mathrm{~mL}$ of mineral-oil based liquid-scintillation solution in each. The liquid-scintillation solution was obtained from the New England Nuclear Corporation. To collect water samples from domestic wells, the tube was attached to a faucet between the wellhead and the storage tank, if present. To collect samples from wellheads that did not have dedicated pumps, a peristaltic or submersible pump was used to supply an uncontaminated, full-column flow to the beaker. A steady stream was allowed to flow out of the beaker for 2 to 3 minutes to purge the beaker and tube and assure a fresh sample. The flow was adjusted to minimize turbulence and to allow excess water to gently spill over the edge of the beaker (EPA, 1978). Water samples from wells were collected by placing the tip of the hypodermic needle about 1 inch below the surface of the water in the beaker.

Equipment used to collect water samples from springs included a syringe and needle, and two glass scintillation vials per site. Water samples from springs were collected by placing the needle below the water surface of the spring as close as reasonably possible to the spring orifice. For each water sample collected, the syringe and hypodermic needle first were rinsed three times by withdrawing a few milliliters of water into the syringe and ejecting it away from the spring.

Twelve to $15 \mathrm{~mL}$ of water then were withdrawn slowly from the beaker or spring to avoid developing a vacuum in the syringe. Rapid withdrawal of the water sample could have reduced 


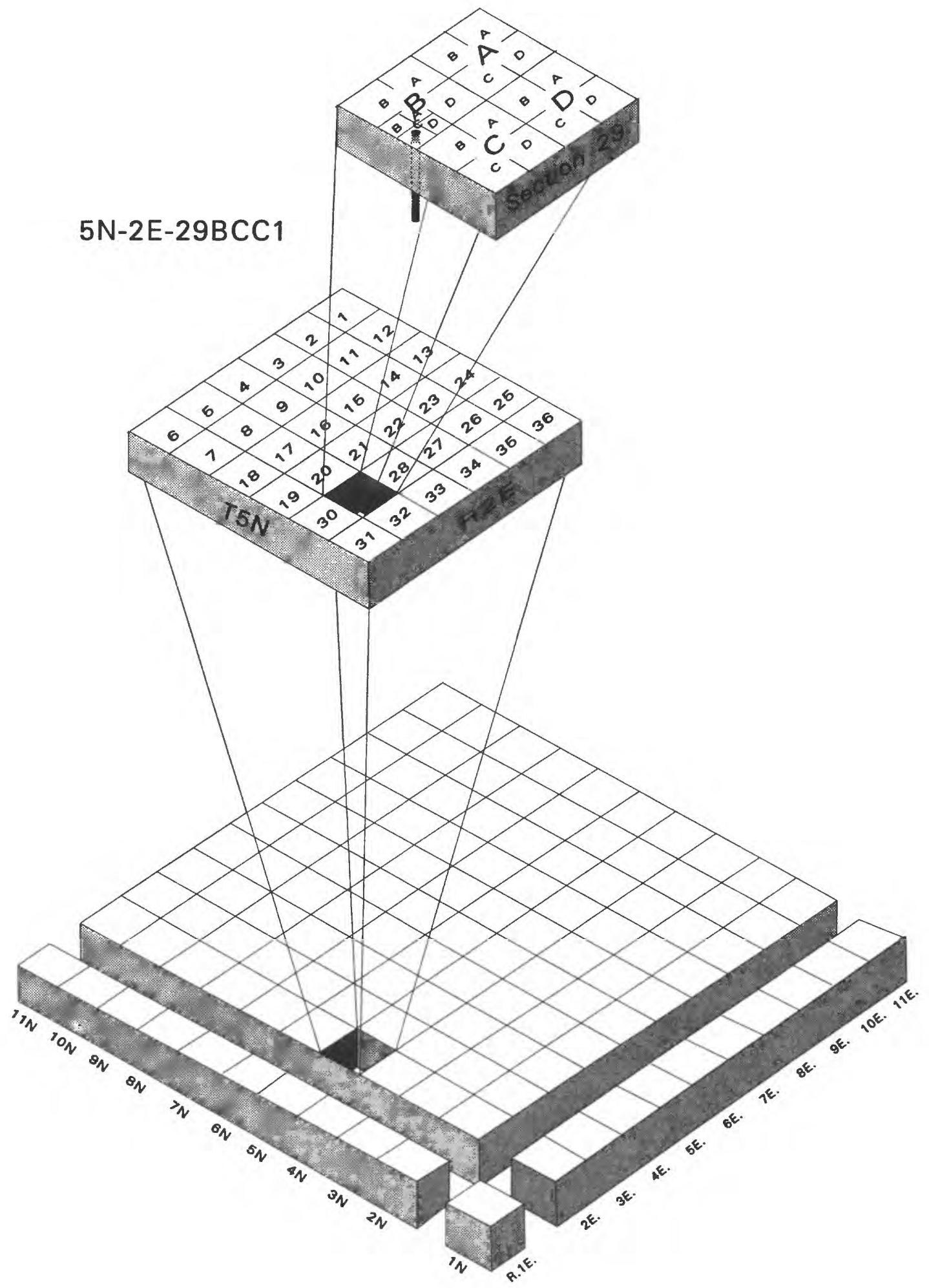

Figure 2.-Well- and spring-numbering system. 
the air pressure, and drawn radon and other dissolved gasses out of solution. The syringe then was pointed upward and any air bubbles and excess water were ejected slowly until $10 \mathrm{~mL}$ of water remained in the syringe. The sample then was ready for transfer to the glass scintillation vial.

The tip of the needle was placed carefully at the bottom of the liquid-scintillation solution in the vial. The water was ejected slowly from the syringe into the vial without causing any turbulence or air bubbles that may have resulted in the loss of radon. The needle was removed from the vial and the cap was tightened securely to prevent leakage. The vial then was shaken vigorously to promote the movement of the radon gas from the water into the liquid-scintillation solution. A small piece of tape was placed on the cap of the vial and the site identification number, sample number, and collection time (date, hour, and minute) were written on the tape. Tape was not placed on the wall of the collection vial and the walls were not marked in any way because this would have interfered with the laboratory analysis.

This procedure was repeated to obtain two separate samples from each well or spring for quality assurance. Collection of sequential samples provided a means of checking analytical reproducibility and monitoring possible radon leakage from a vial. The two vials were placed in a small, foam-packed cardboard box and sent by overnight delivery to the USGS National Water Quality Laboratory in Arvada, Colorado. The concentration reported for dissolved radon for a given sampling site is an average of the concentration in the two vials except in those instances where a vial leaked or broke during shipment.

Water-sample analysis was by direct liquidscintillation counting (Pritchard and Gesell, 1977). Each vial, with a $10-\mathrm{mL}$ water sample and $10 \mathrm{~mL}$ of the liquid-scintillation solution, was shaken in the laboratory to mix the fluids. After a 3-hour waiting period, the radioactivity was measured using a commercial liquid-scintillation counter. The measurement of radioactivity for each sample was then converted to a radon- 222 concentration and decay corrected to the time of sample collection. The analytical method detection limit is about $80 \mathrm{pCi} / \mathrm{L}$ for a $10-\mathrm{mL}$ water sample.

\section{Acknowledgments}

The authors gratefully acknowledge the many landowners and water users who allowed access to their property for collection of water samples.

\section{CONCENTRATIONS OF DISSOLVED RADON-222}

Water samples were collected from 338 Idaho wells and springs during 1989-91 for radon-222 analyses. Concentrations of dissolved radon-222 are presented in table 1 (at back of report). Locations of wells and springs sampled for radon are shown on figures 3-9 (at back of report). Concentrations are presented as an analytical result with an analytical uncertainty as two sample standard deviations (2s), for example, $132 \pm 33$ $\mathrm{pCi} / \mathrm{L}$. The last two columns in table 1 present an average concentration and calculated experimental standard error for each pair of water samples. Only paired observations were used for the descriptive statistics. If more than one pair of samples were taken on a given day for a site, only the first sample pair taken that day was used for the statistics.

Negative radon-222 concentrations occurred if the radioactivity (due to radon-222) in a water sample was less than the background radioactivity or the radioactivity of the prepared blank sample in the laboratory. The associated uncertainty presented with the overall mean concentration of the 372 pairs of water samples used for statistics was a calculated experimental standard error and was an estimate of the uncertainty of the mean concentration (Iman and Conover, 1983, p. 158). The average concentations of dissolved radon-222 in the 372 pairs of water samples ranged from $-58 \pm 30$ to $5,715 \pm 66 \mathrm{pCi} / \mathrm{L}$; the mean and median concentrations were $446 \pm 35$ and $242 \pm 25 \mathrm{pCi} / \mathrm{L}$, respectively. 


\section{REFERENCES CITED}

Cecil, L.D., and Gesell, T.F., 1992, Sampling and analysis for radon-222 dissolved in ground water and surface water: Environmental Monitoring and Assessment, v. 20: p. 55-66.

Claassen, H.C., 1982, Guidelines and techniques for obtaining water samples that accurately represent the water chemistry of an aquifer: U.S. Geological Survey Open-File Report 82-1024, 49 p.

Cothern, C.R., 1987, Estimating the health risk of radon in drinking water, Journal of the American Water Well Association, v. 70, no. 4, p. 153-158.

Iman, R.L., and Conover, W.J., 1983, A modern approach to statistics: John Wiley and Sons, Inc., New York, 497 p.

Prichard, H.M., and Gesell, T.F., 1977, Rapid measurements of ${ }^{222} \mathrm{Rn}$ concentrations in water with a commercial liquid scintillation counter: Health Physics, v. 33, p. 577-581.

U.S. Environmental Protection Agency, 1978, Radon in water sampling program: EPA/EERF-Manual78-1, $11 \mathrm{p}$.

---- 1991, National primary drinking water regulations; radionuclides; proposed rule: Federal Register, v. 56 , no. 138 , p. 33,050-33, 127.

Wood, W.W., 1981, Guidelines for collection and field analysis of ground-water samples for selected unstable constituents: U.S. Geological Survey Techniques of Water-Resources Investigations, Book 1, Chap. D2, 24 p. 


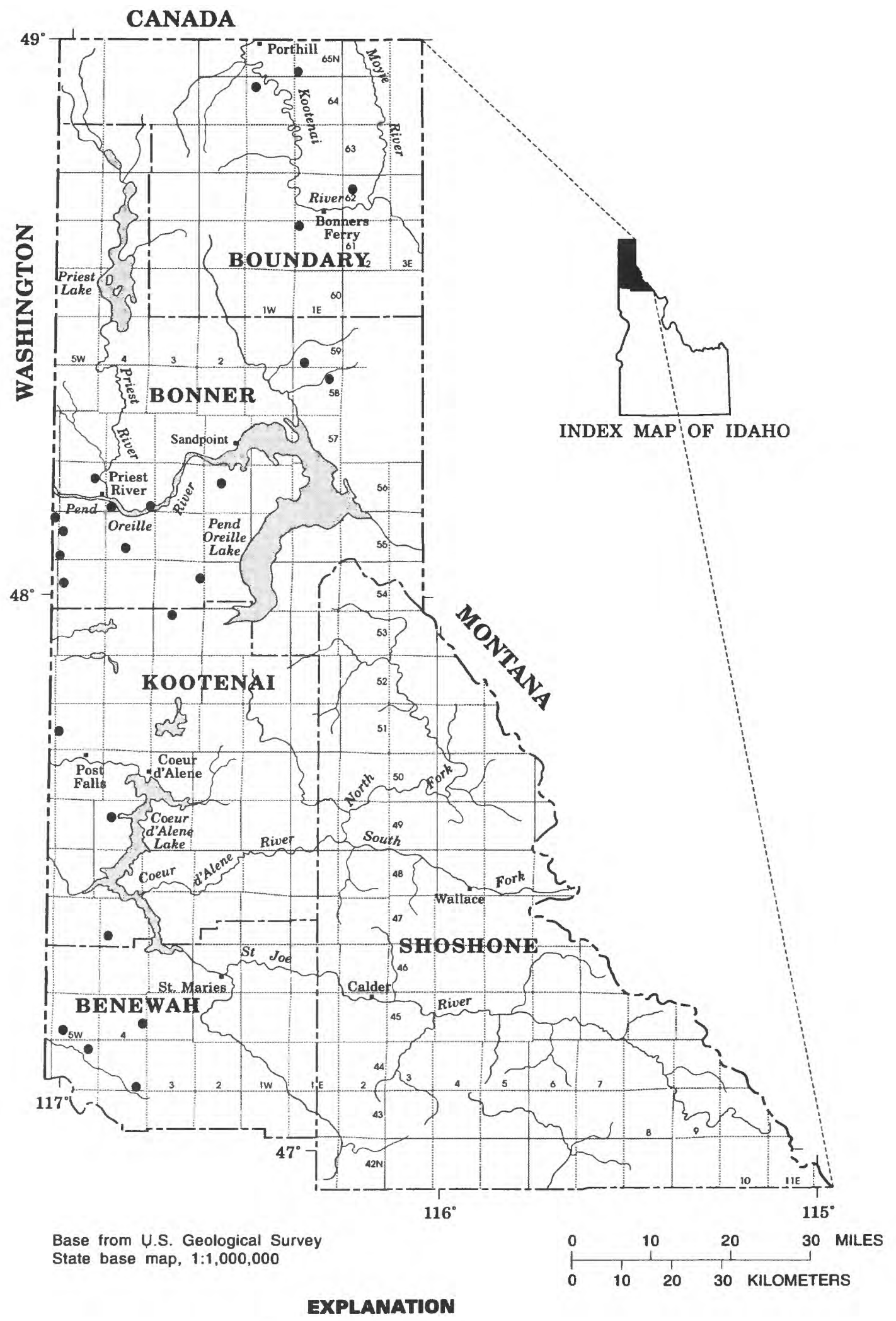

- WELL OR SPRING

Figure 3.-Location of wells and springs sampled for radon in north Idaho. 


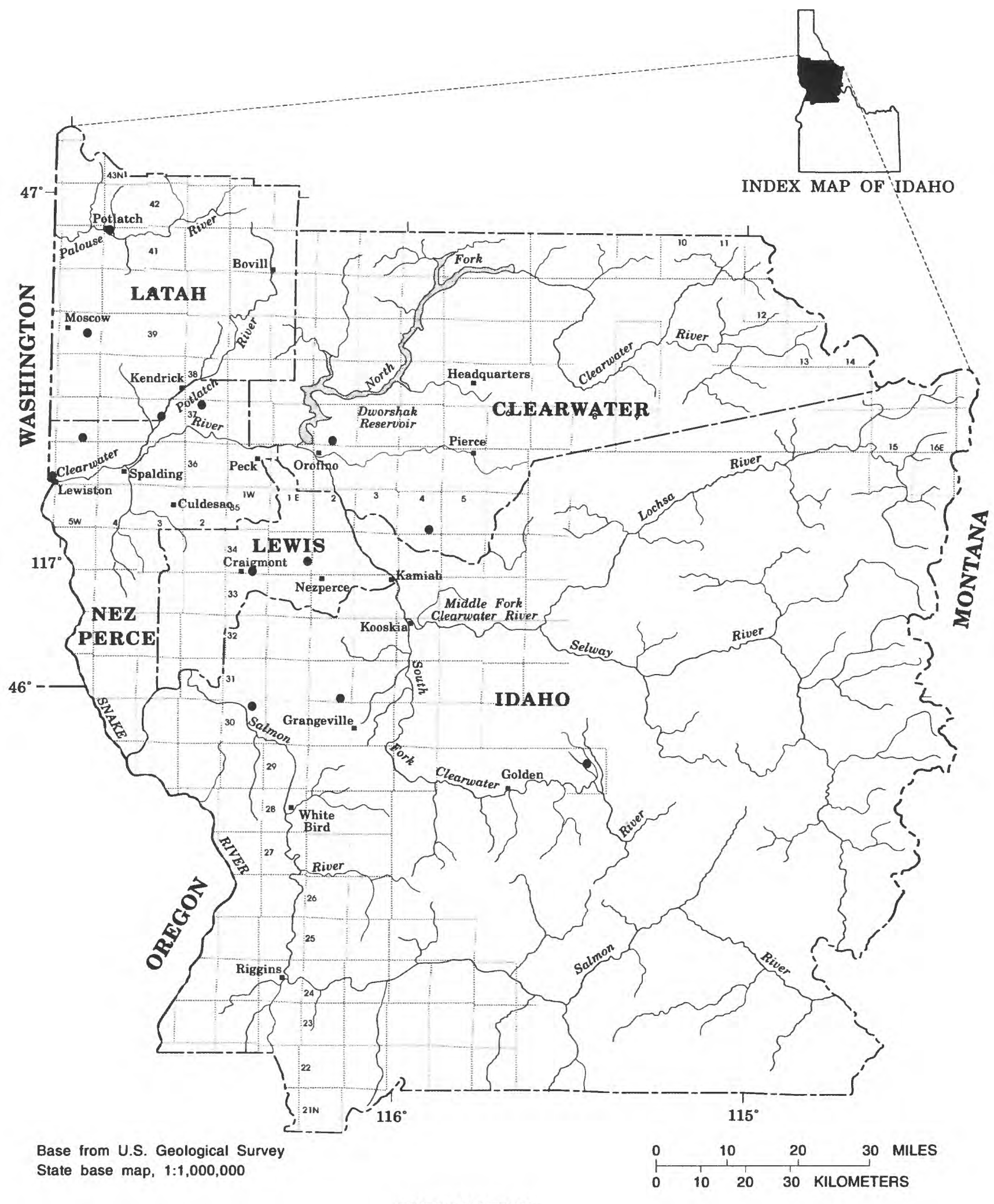

EXPLANATION

- WELL OR SPRING

Figure 4.-Location of wells and springs sampled for radon in north-central Idaho. 


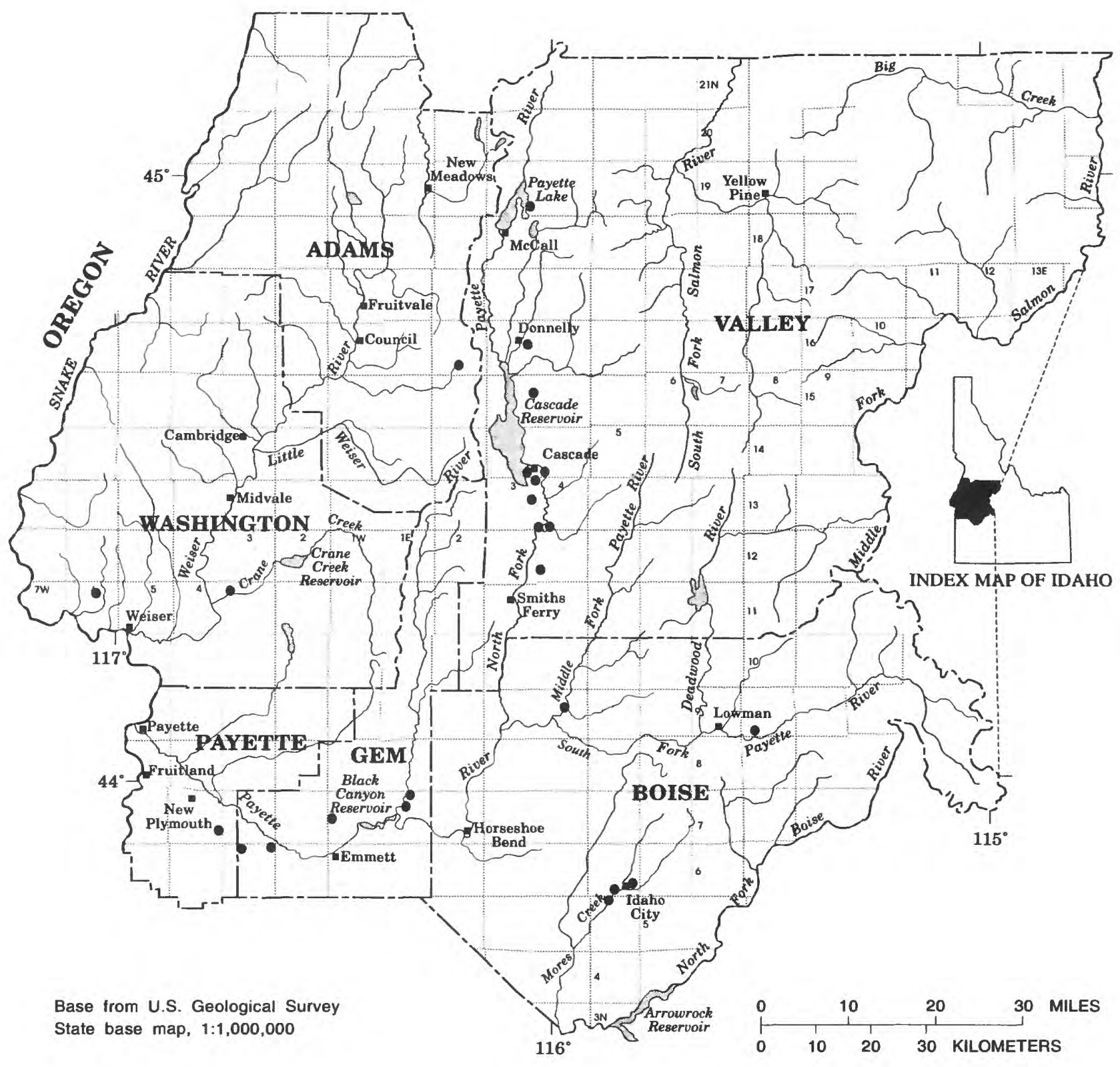

EXPLANATION

- Well or SPRing

Figure 5.-Location of wells and springs sampled for radon in west-central Idaho. 


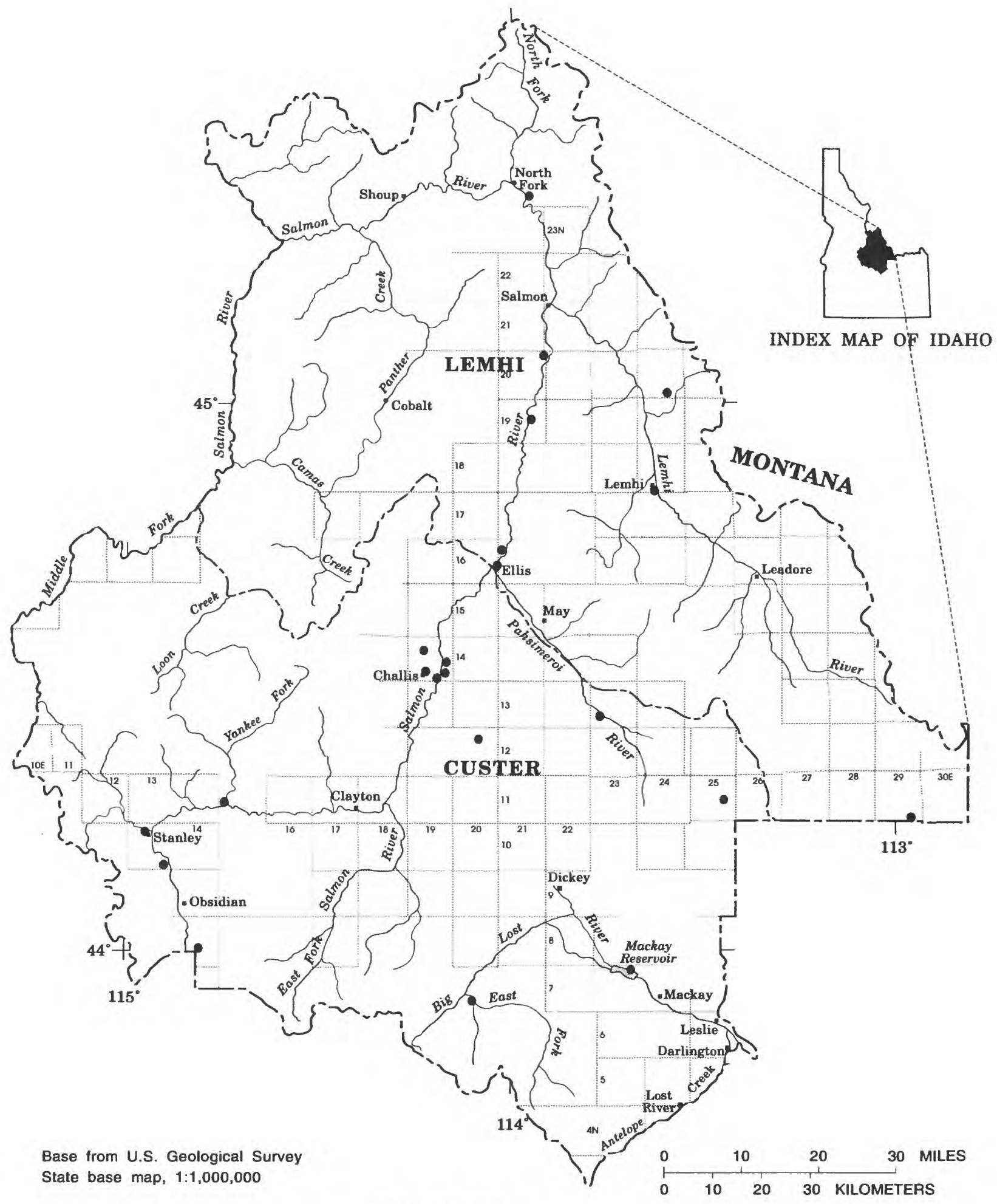

EXPLANATION

- WELL OR SPRING

Figure 6.-Location of wells and springs sampled for radon in east-central Idaho. 


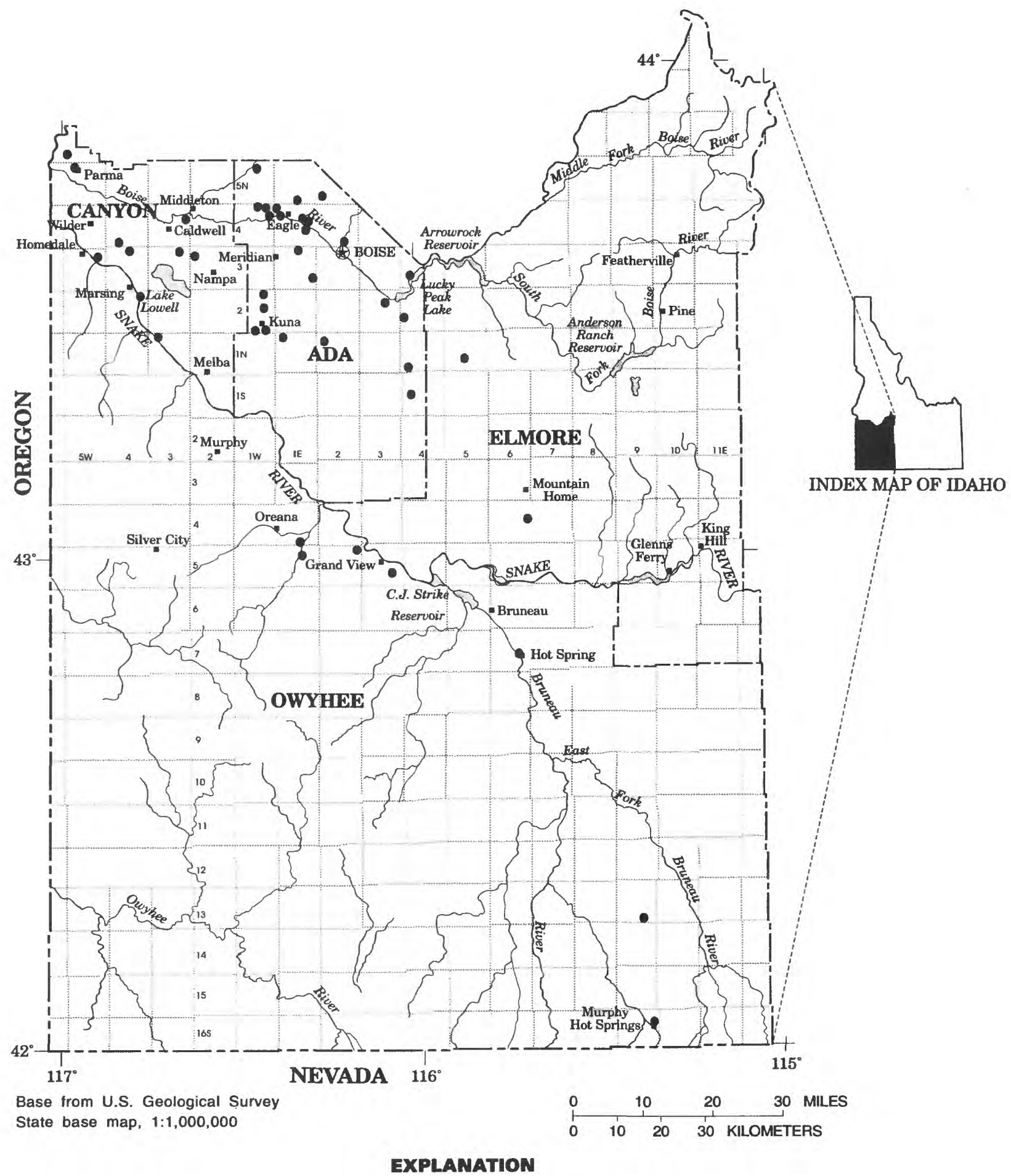

- WELl OR SPRING

Figure 7.-Location of wells and springs sampled for radon in southwest Idaho. 


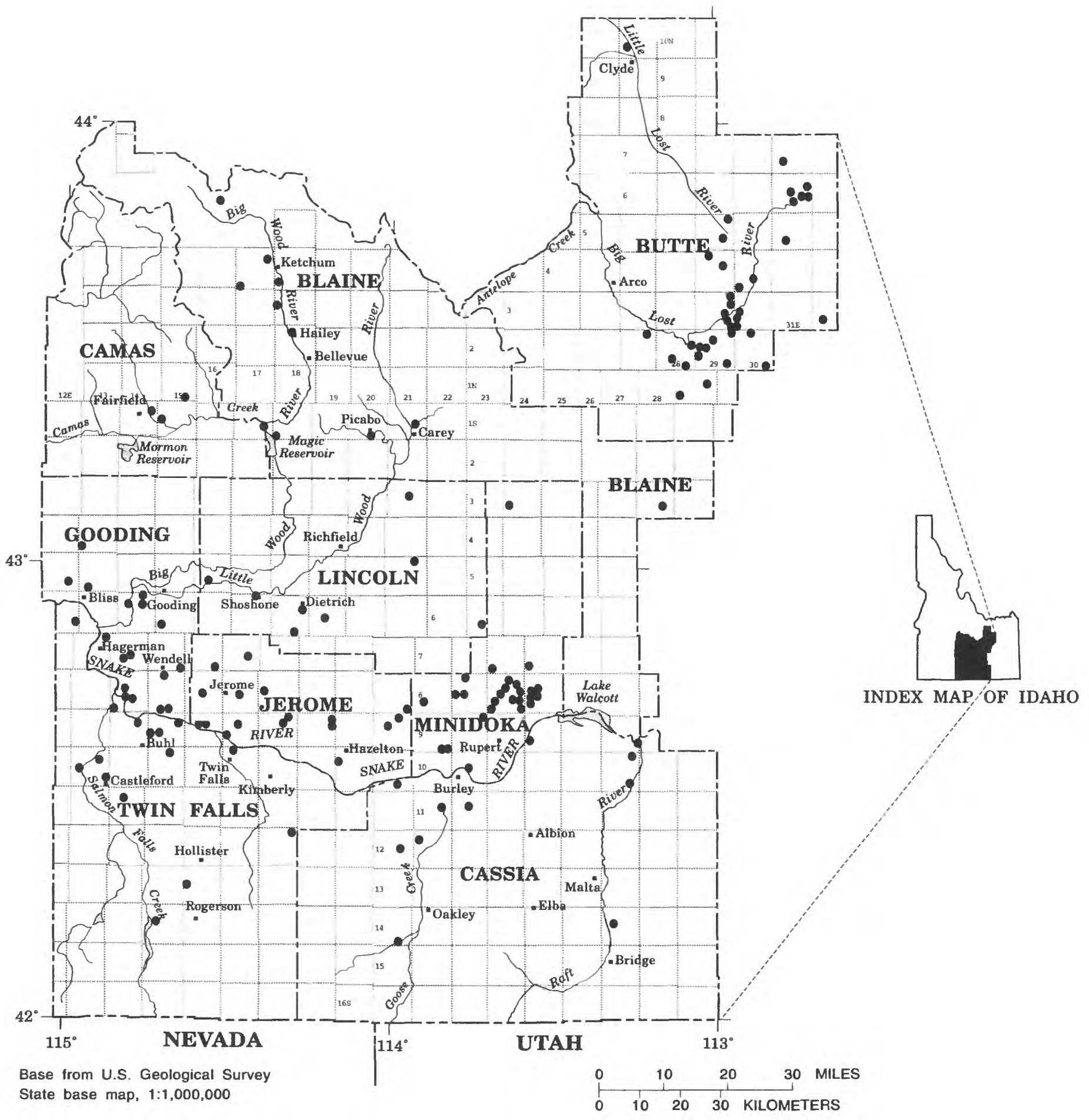

EXPLANATION

- WELL OR SPRING

Figure 8.-Location of wells and springs sampled for radon in south-central Idaho. 


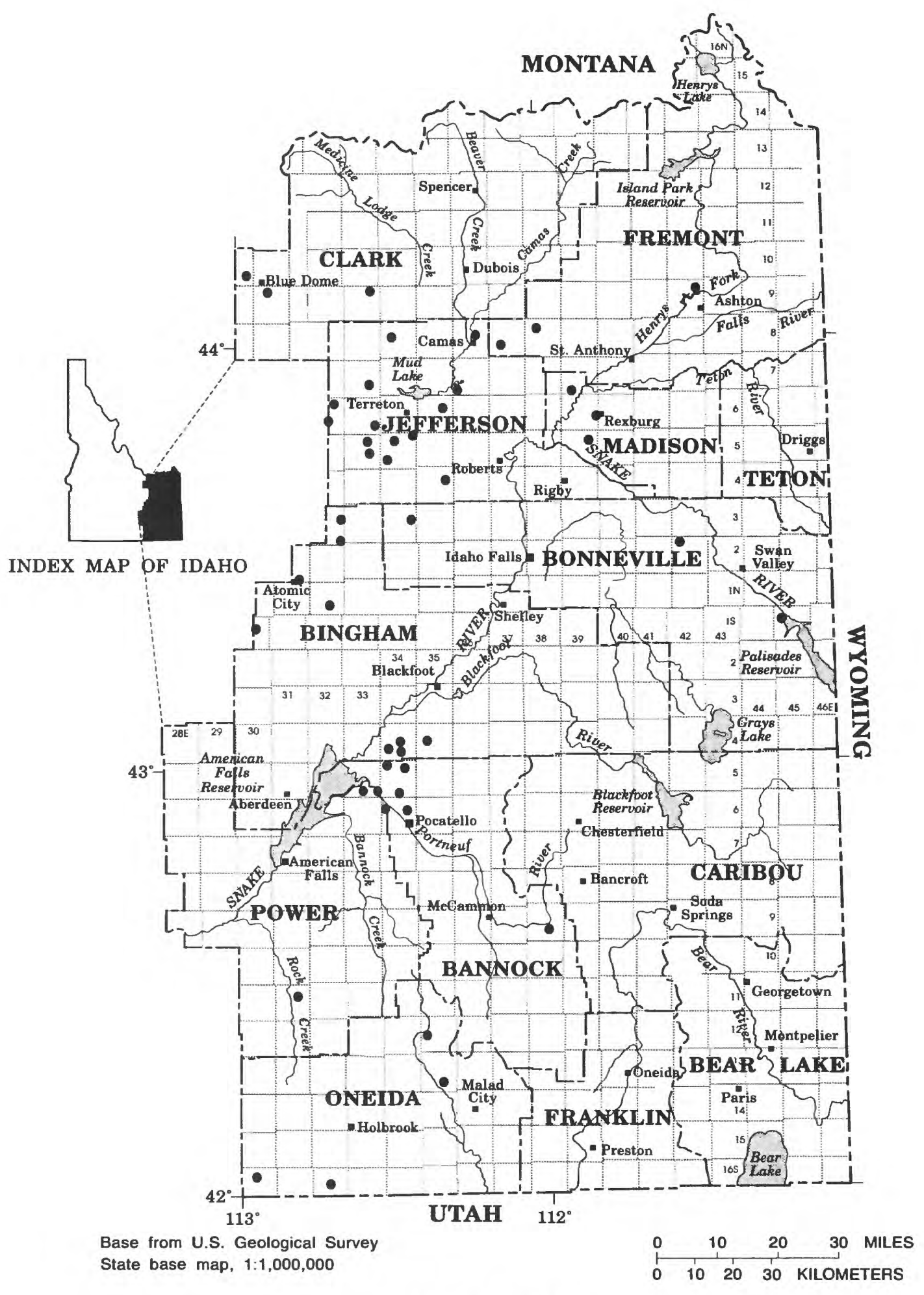

EXPLANATION

- WELL OR SPRING

Figure 9.-Location of wells and springs sampled for radon in southeast Idaho. 


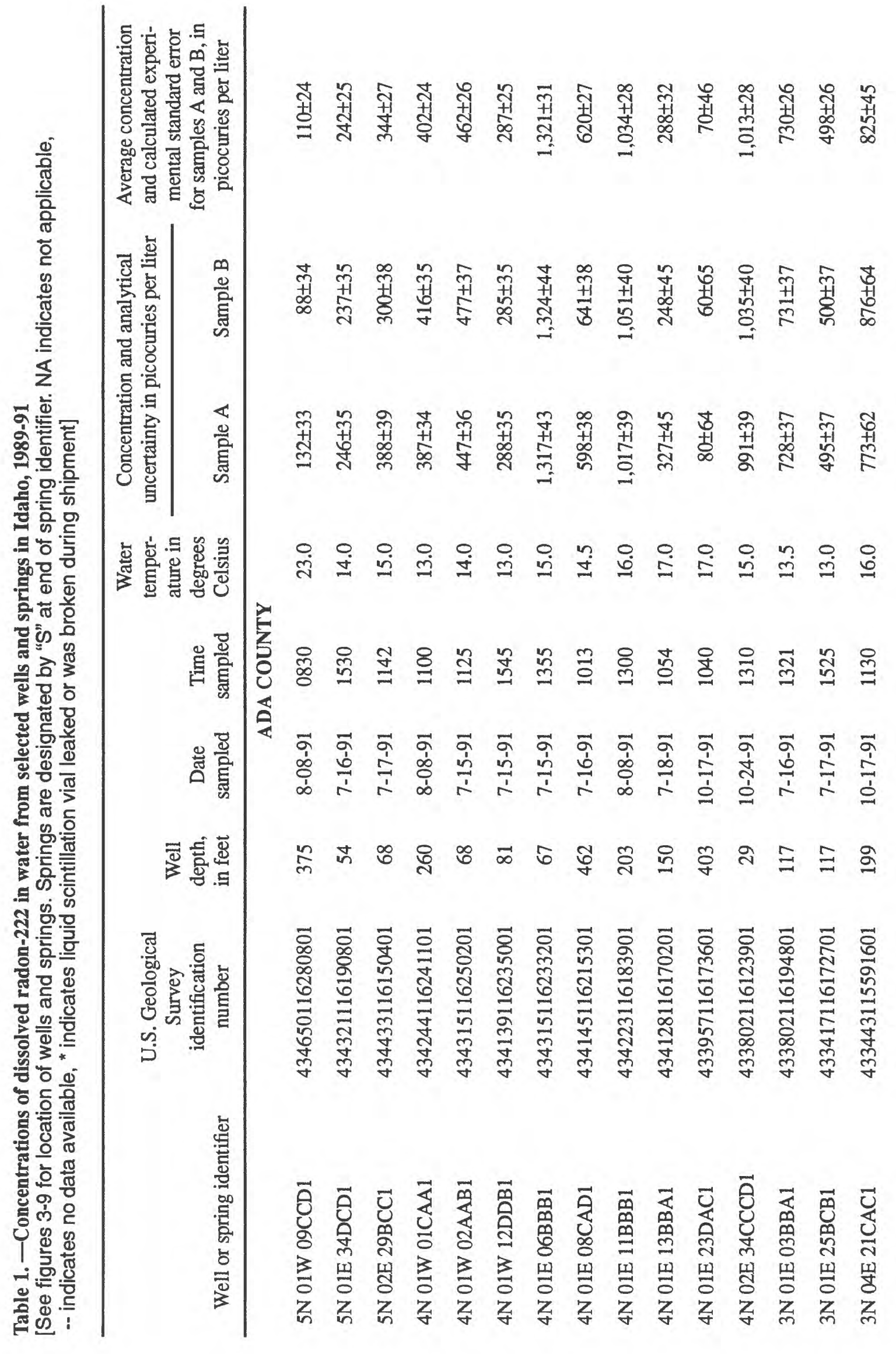




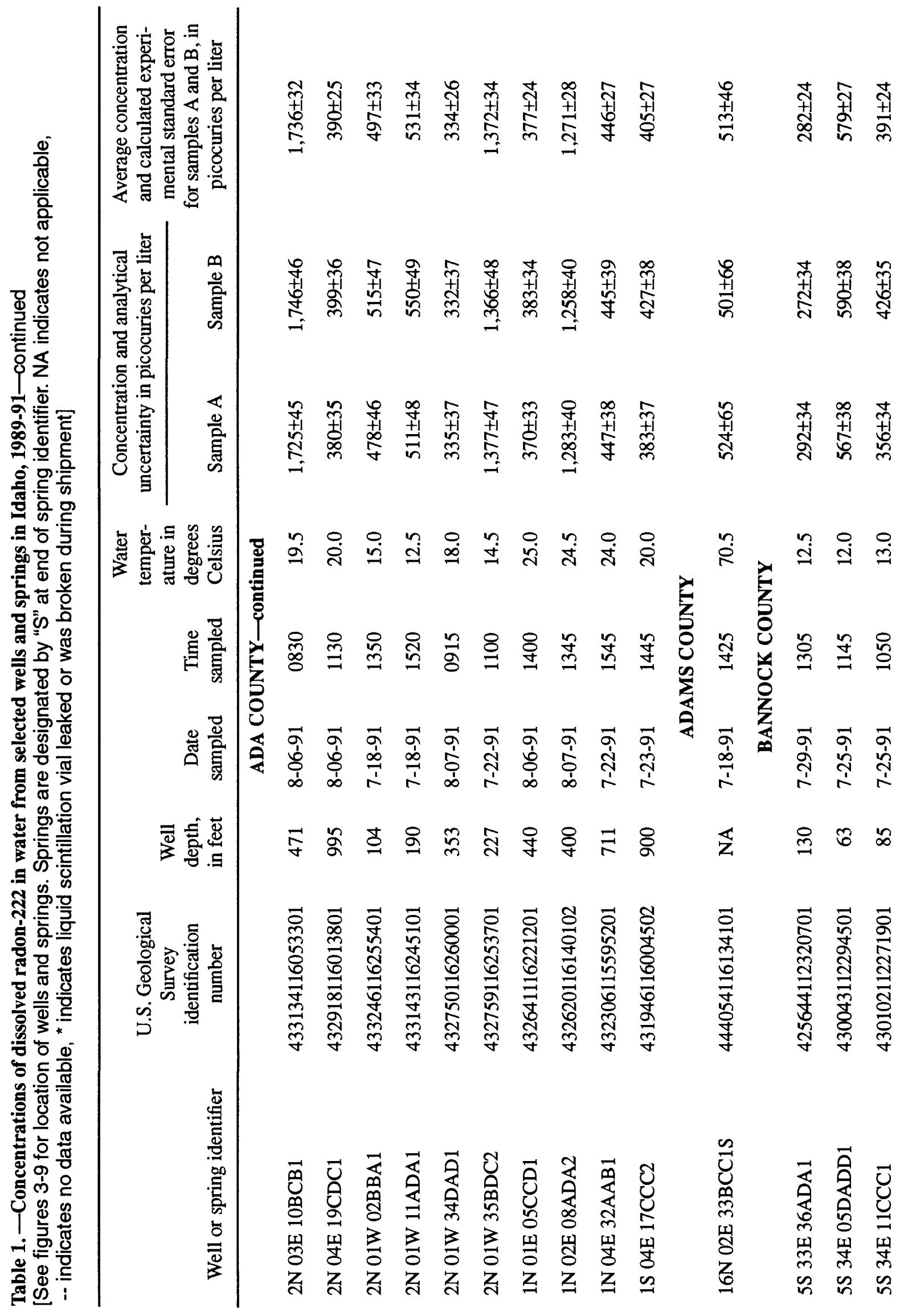




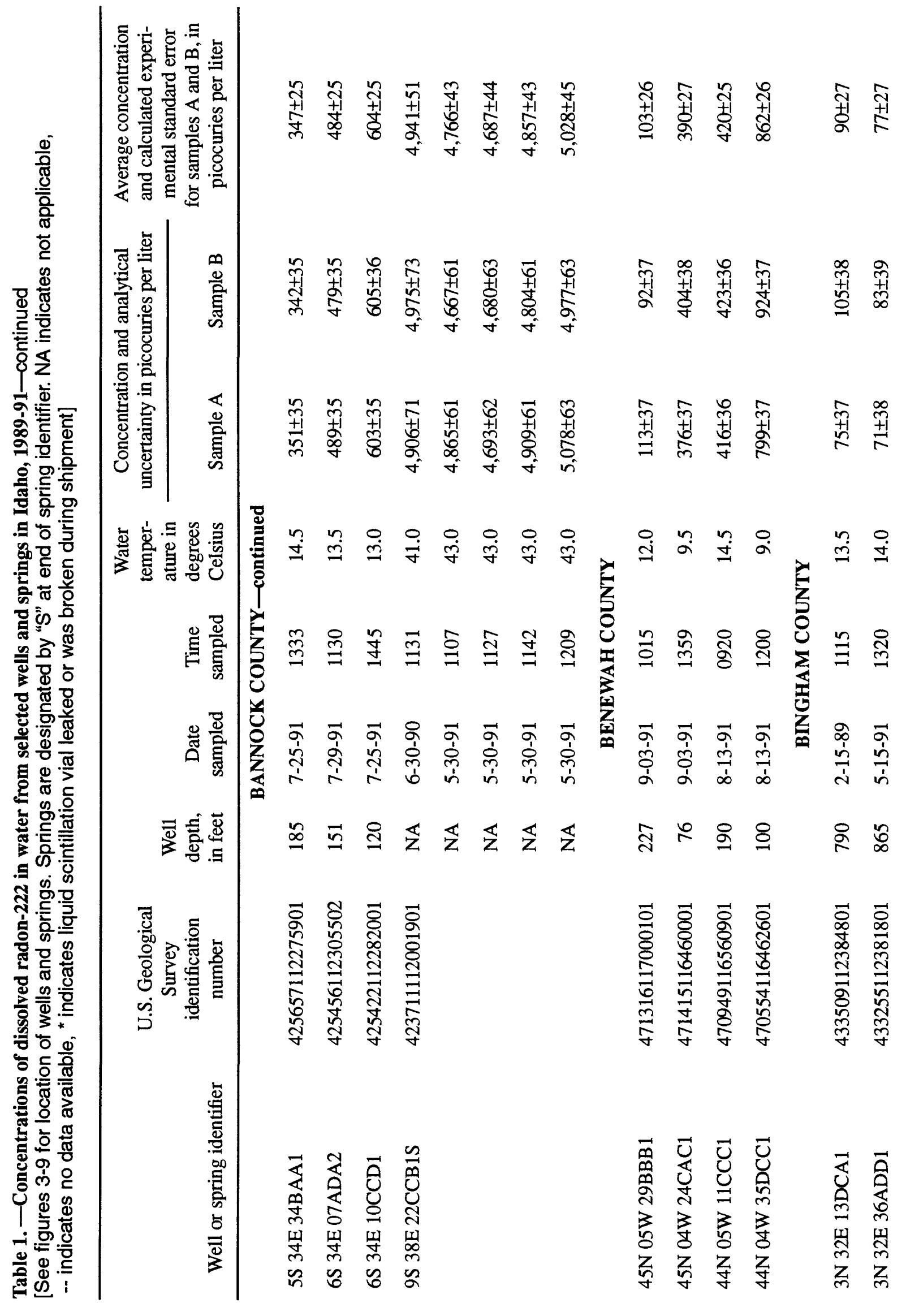




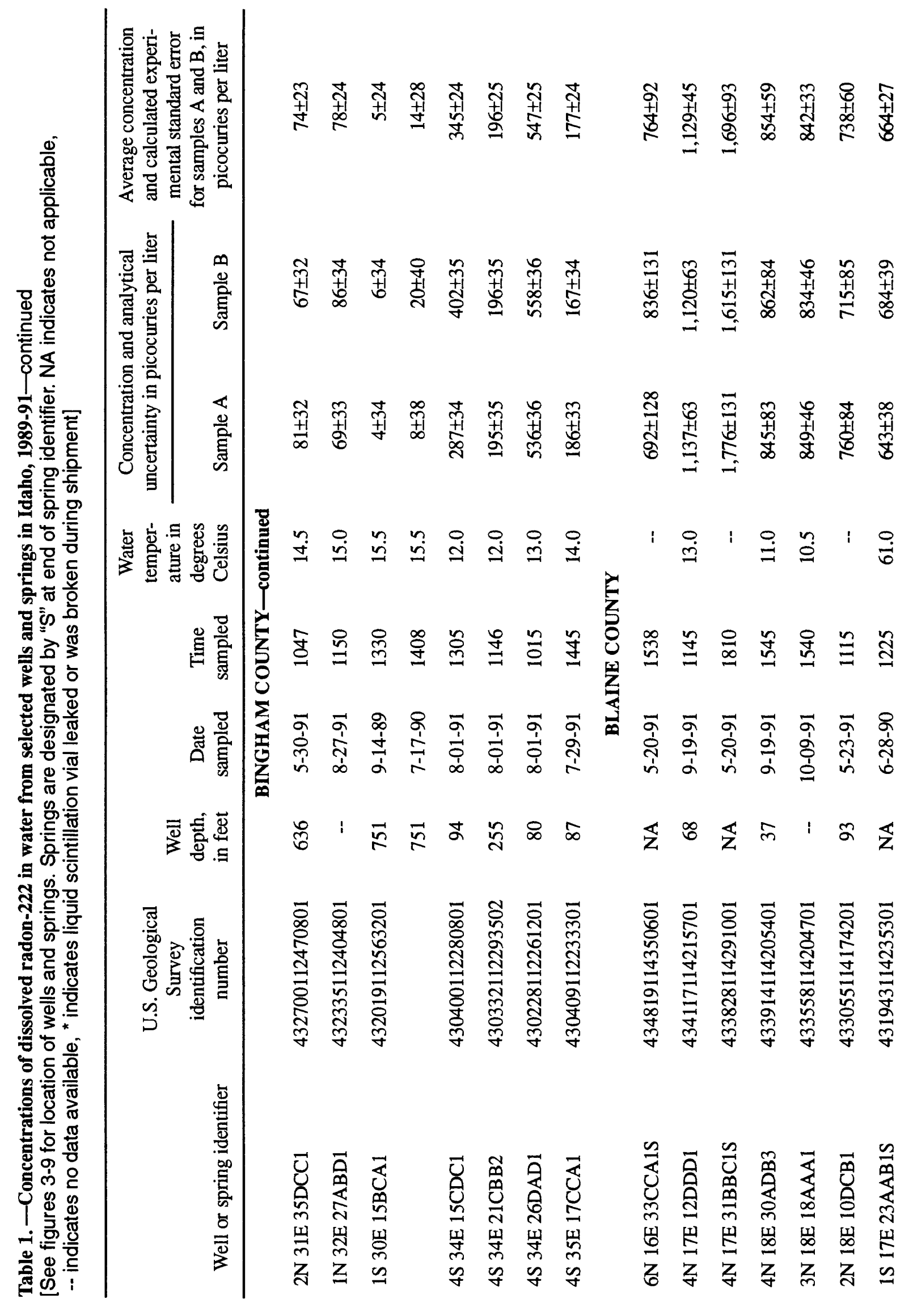




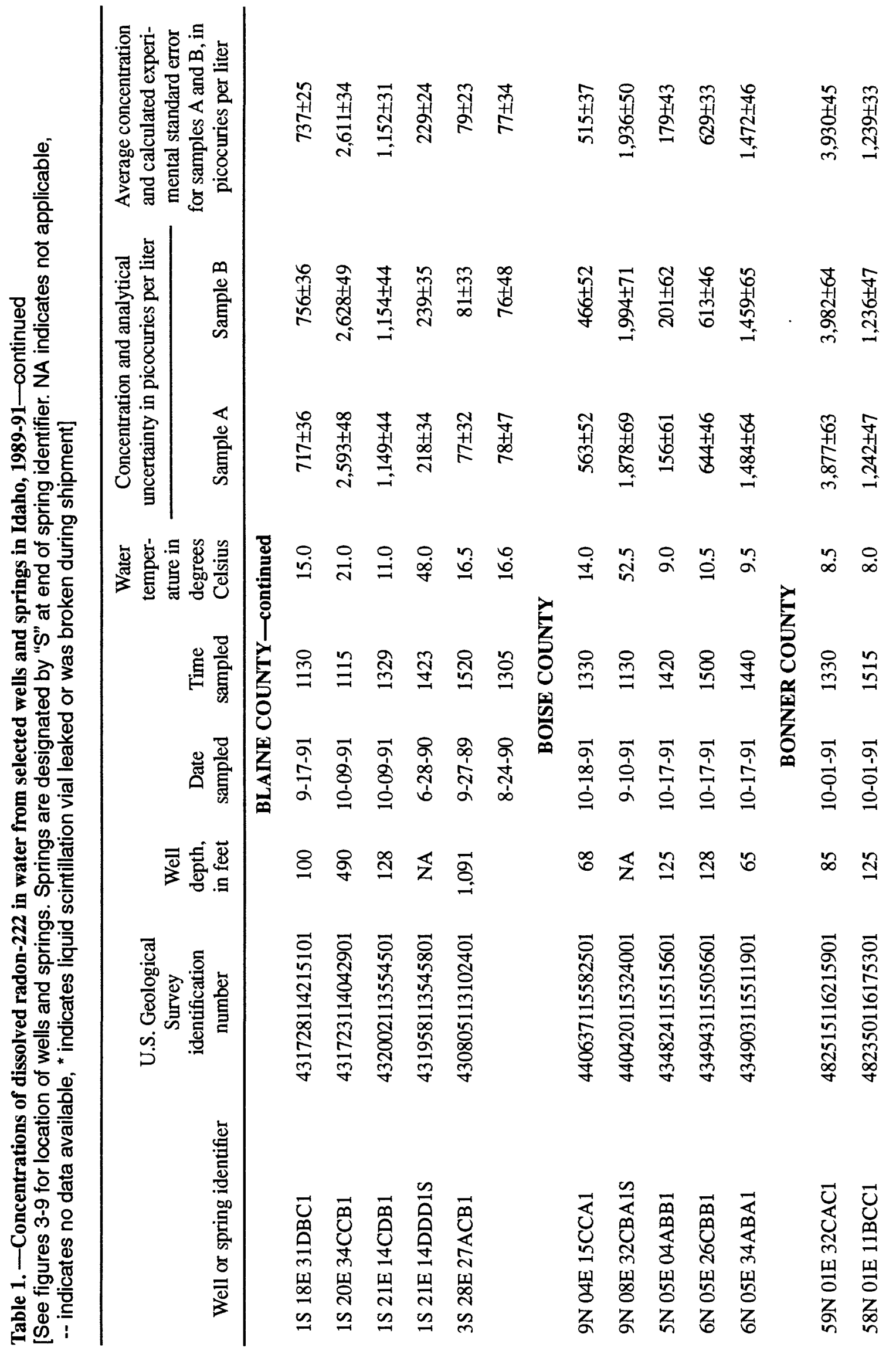




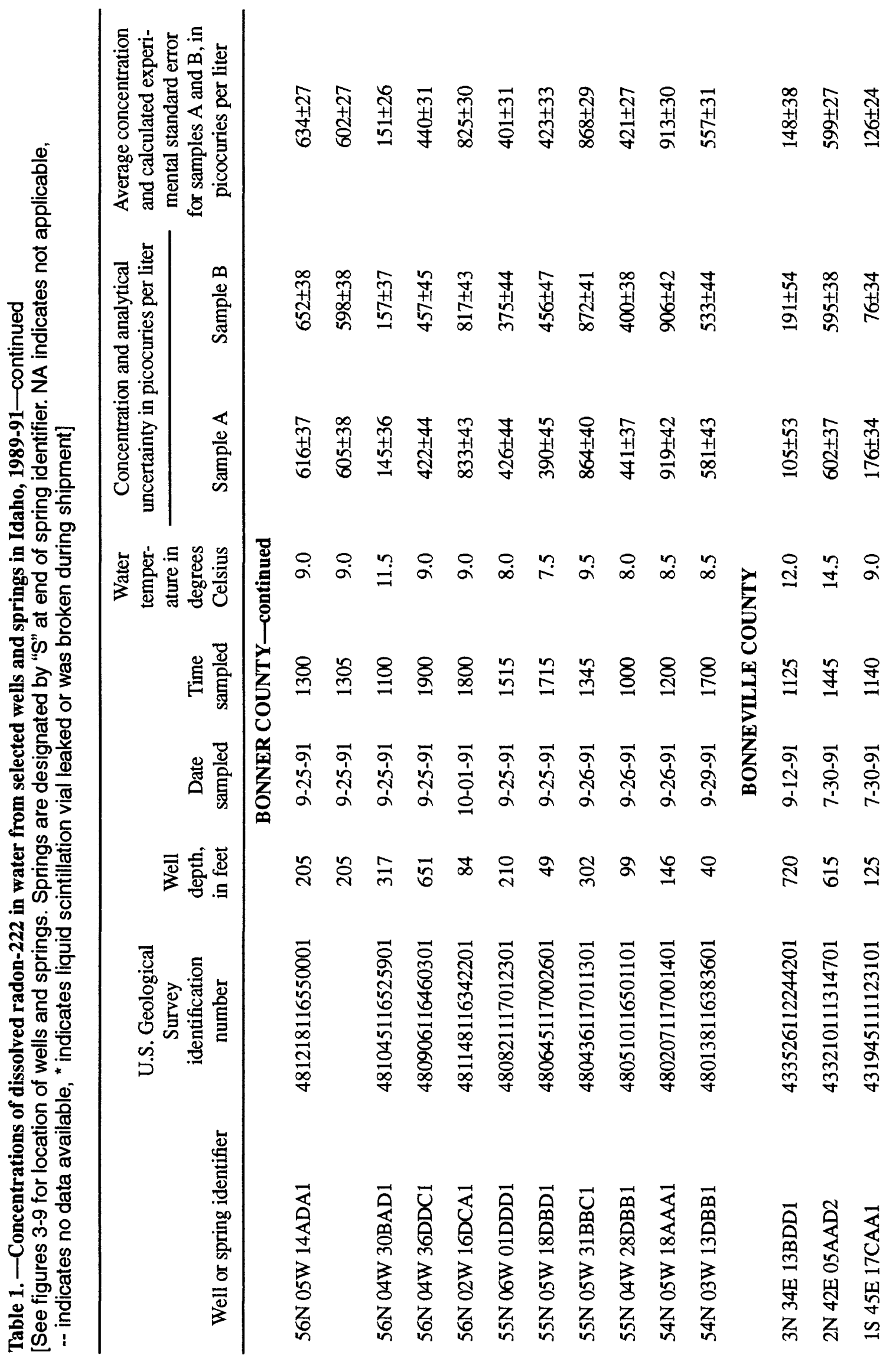




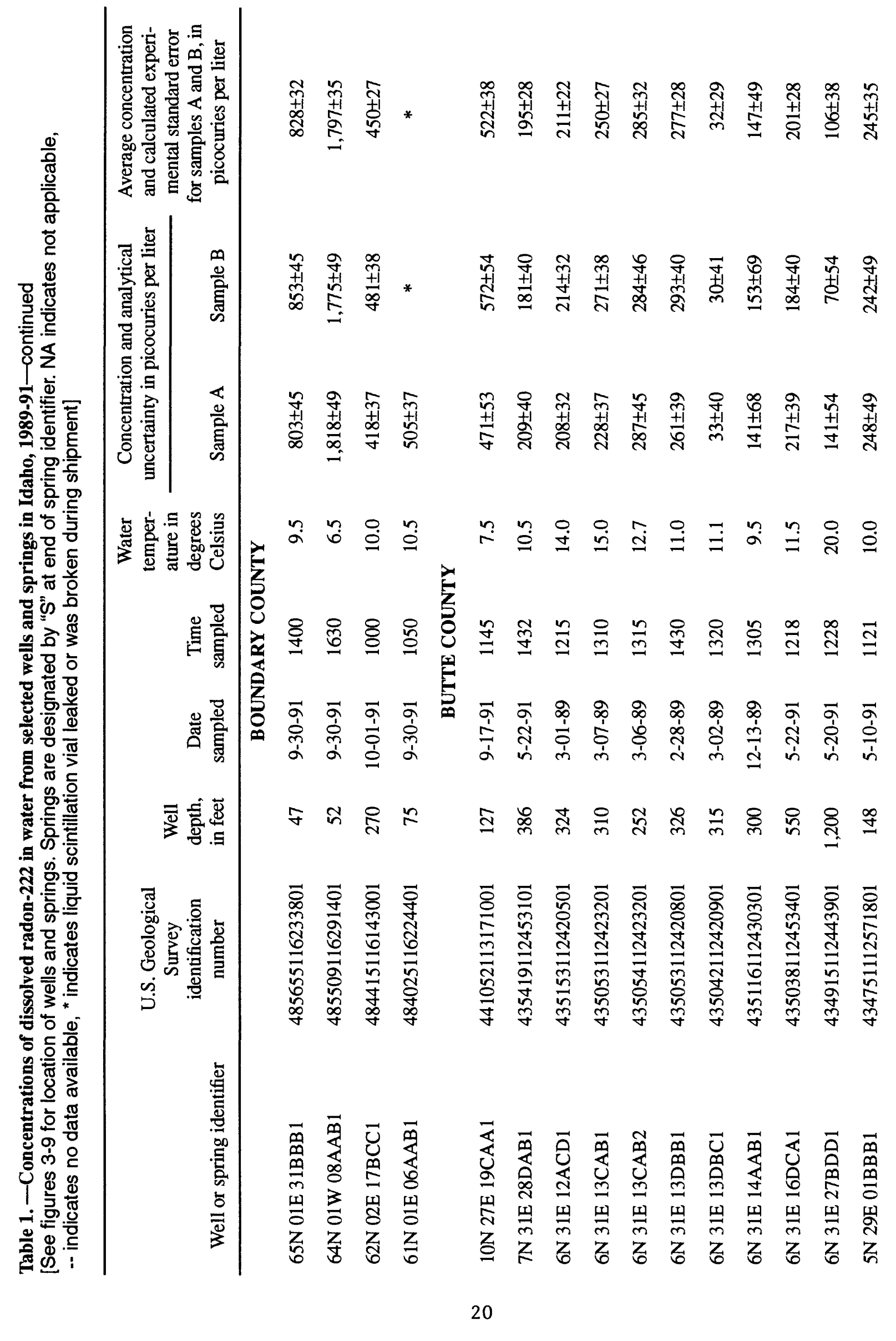




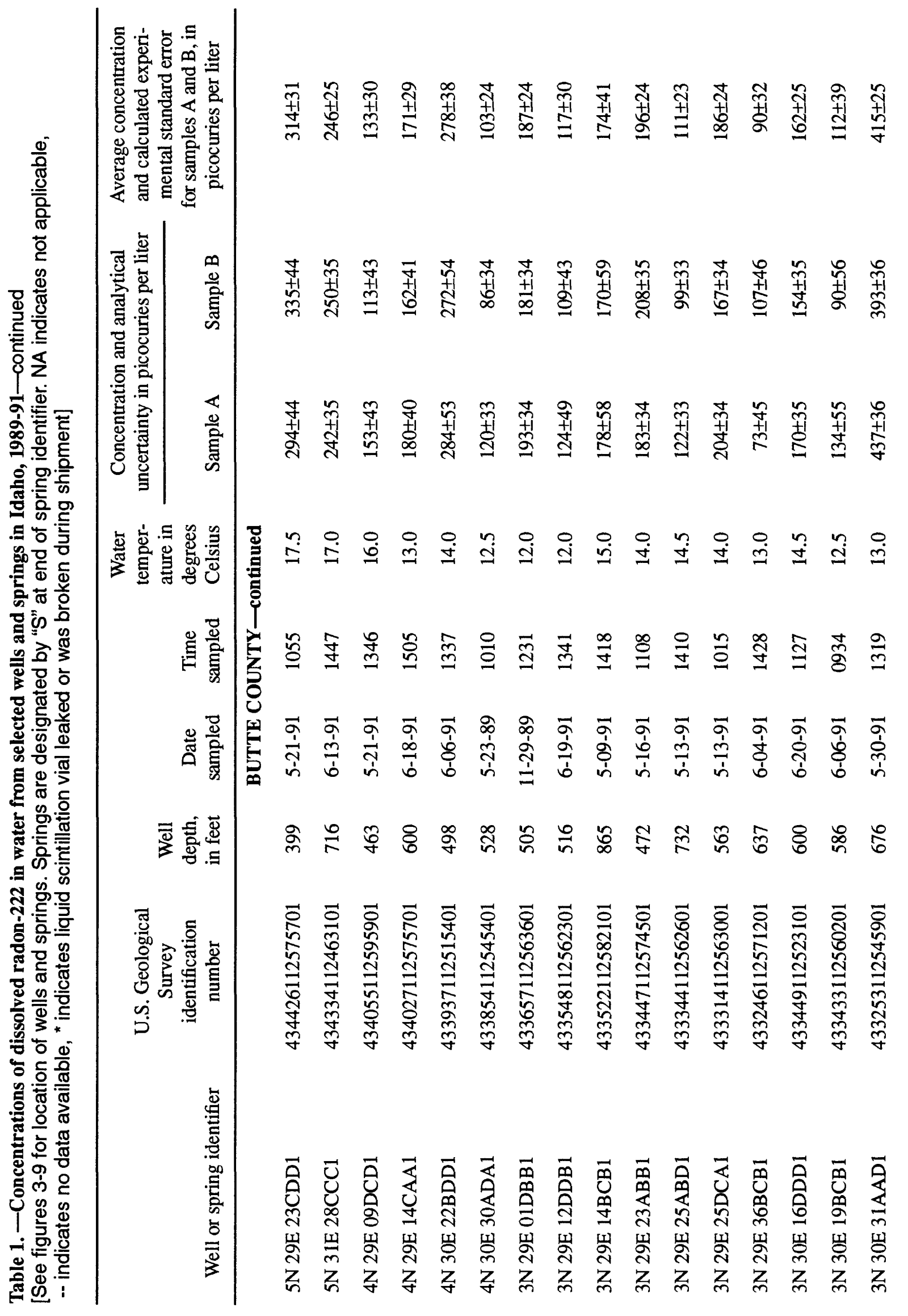




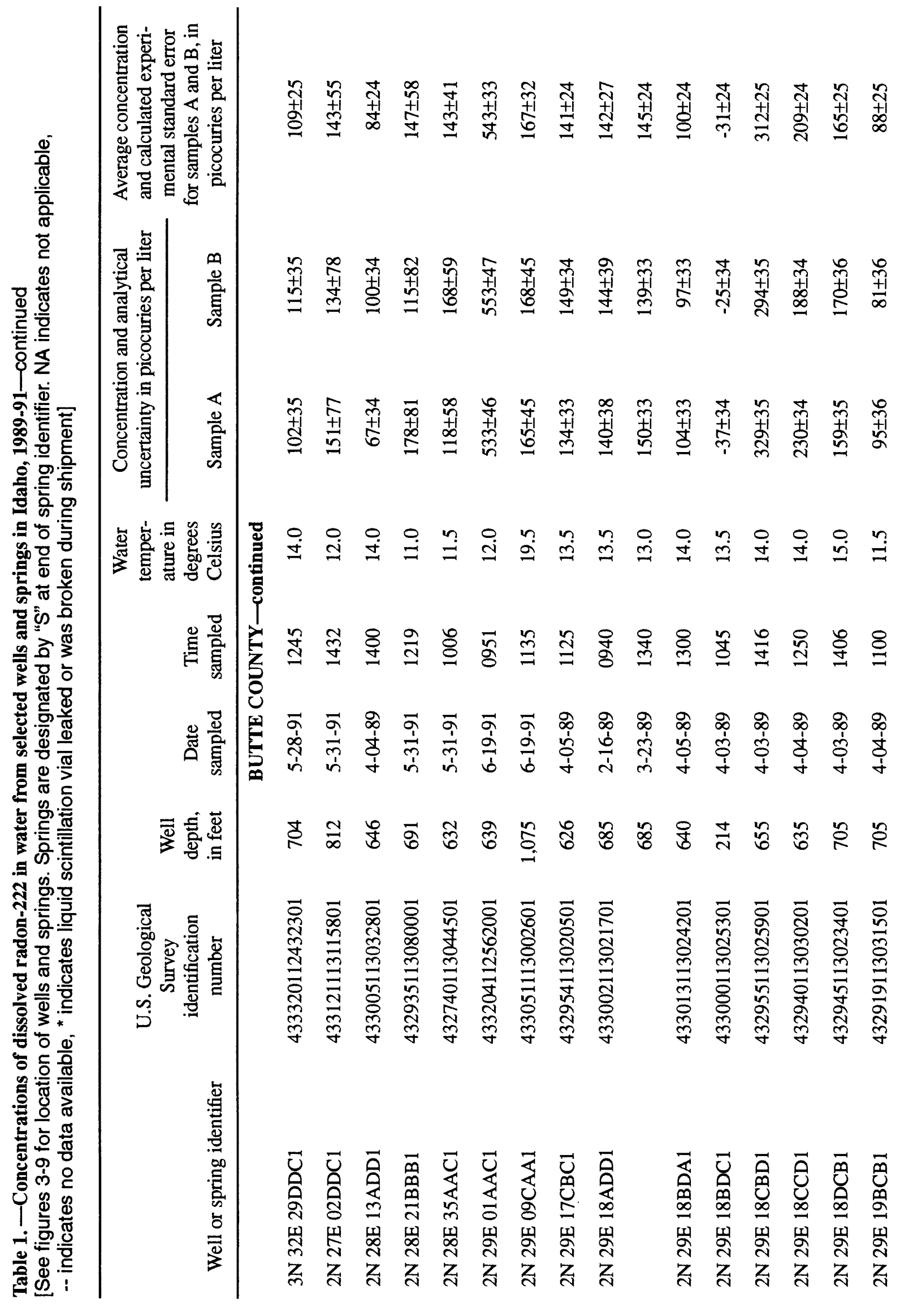




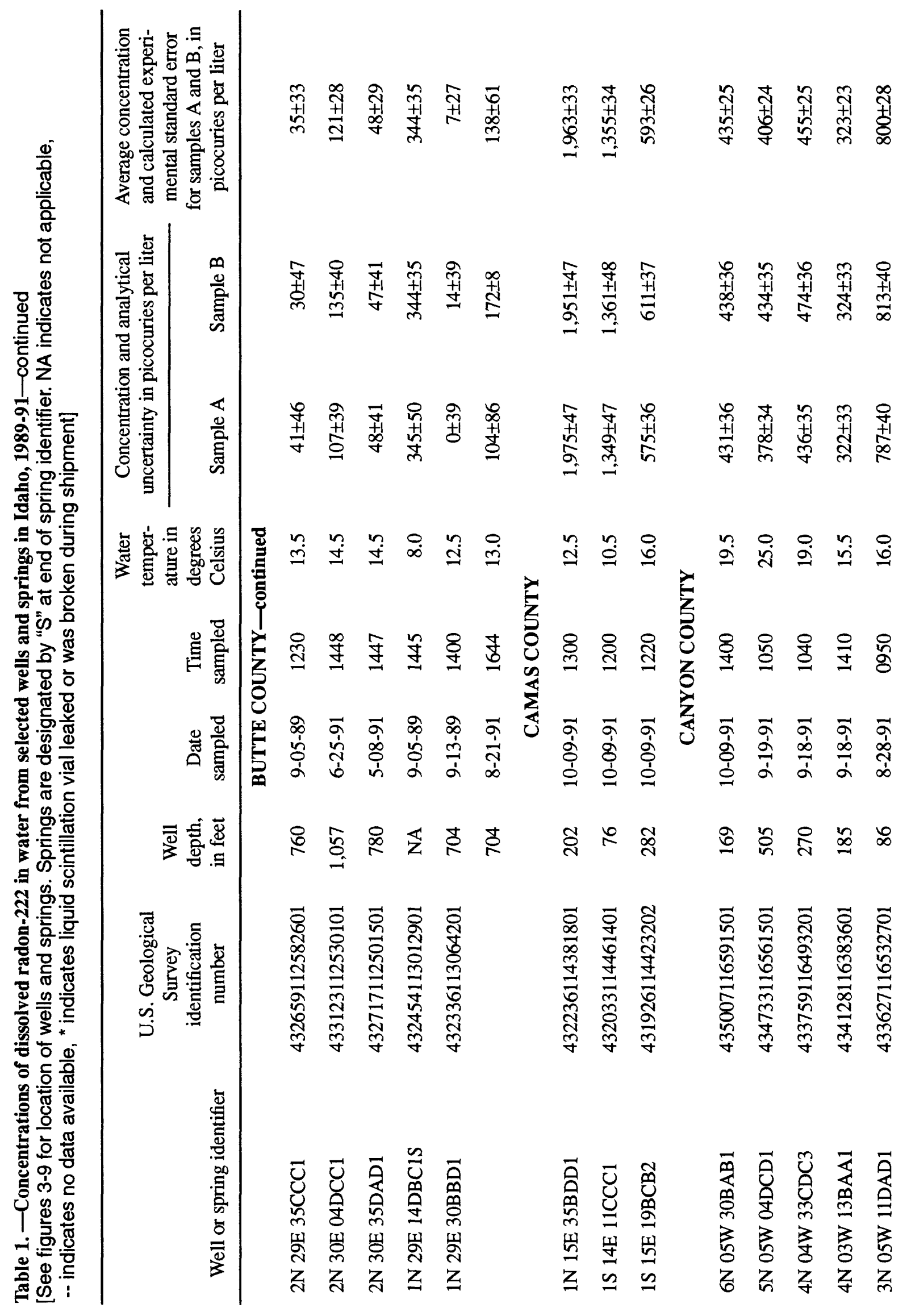




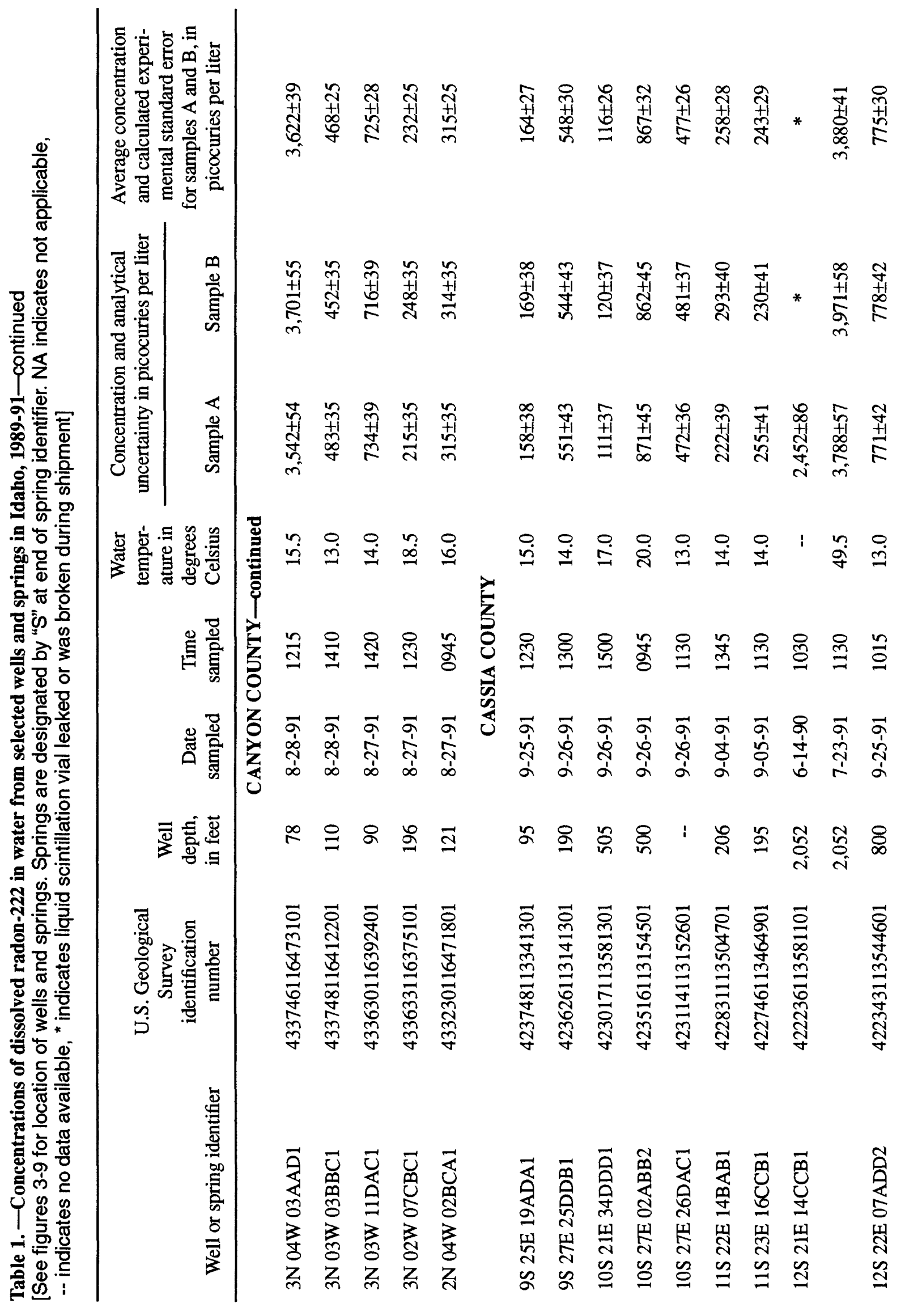




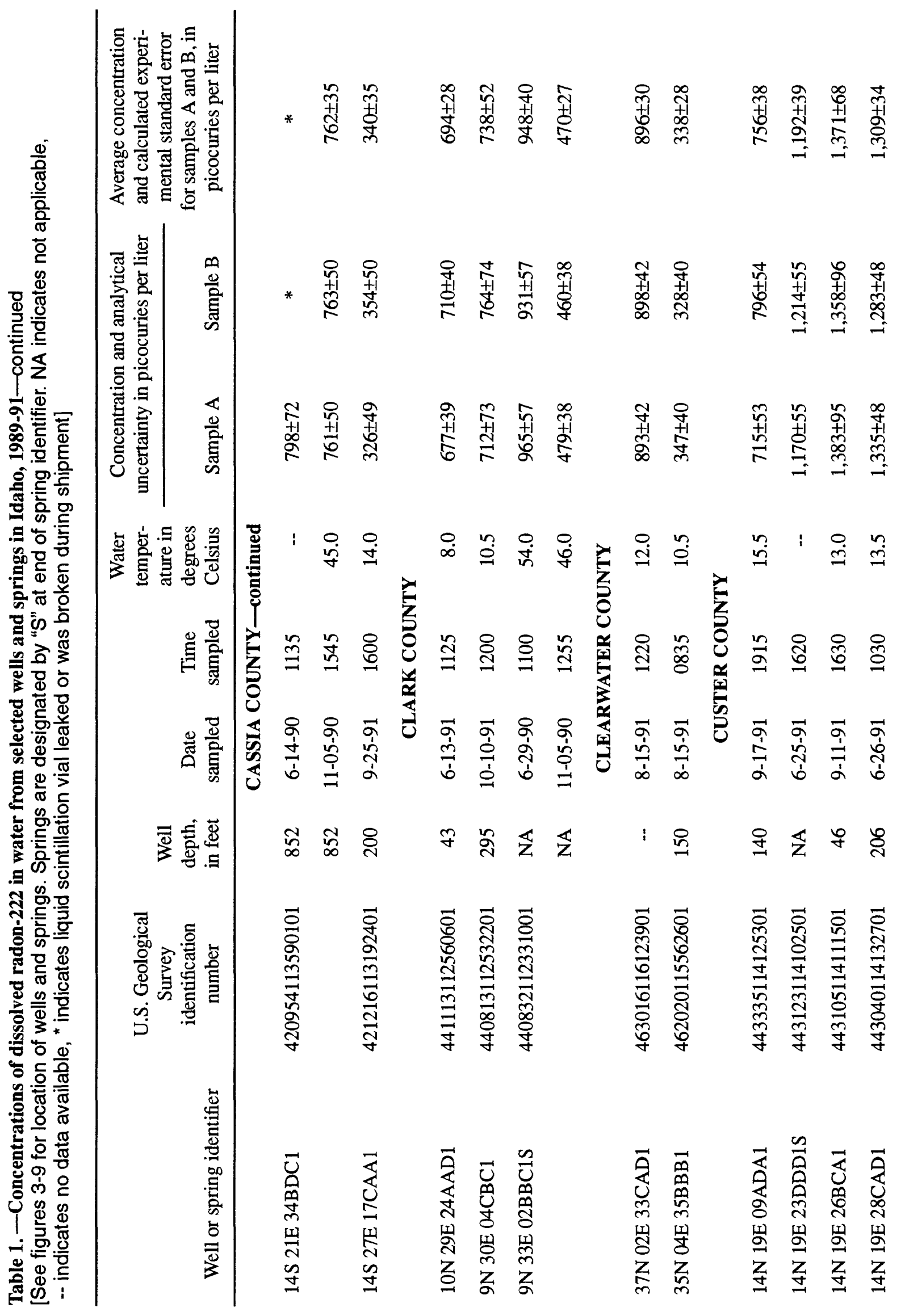




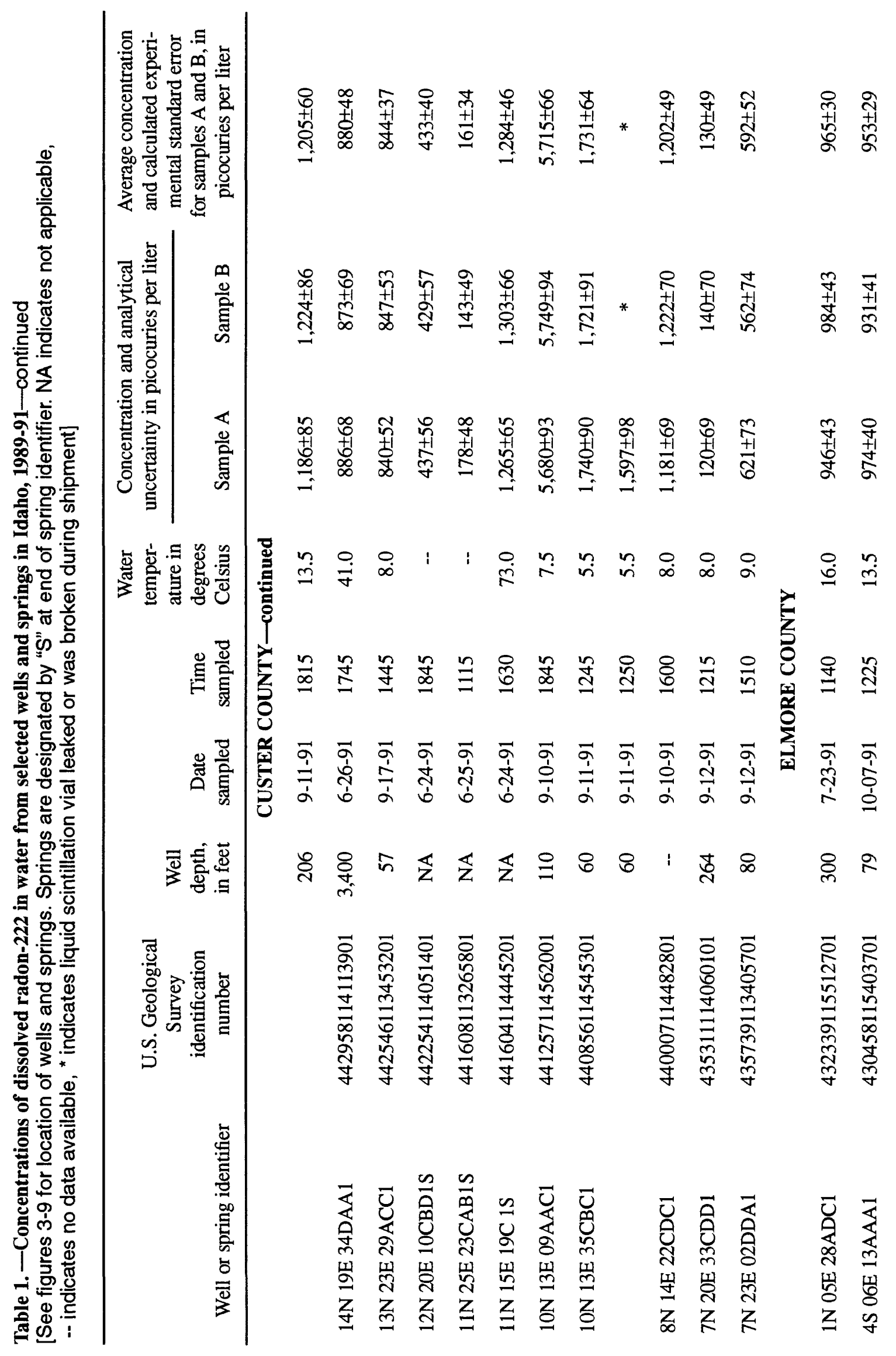




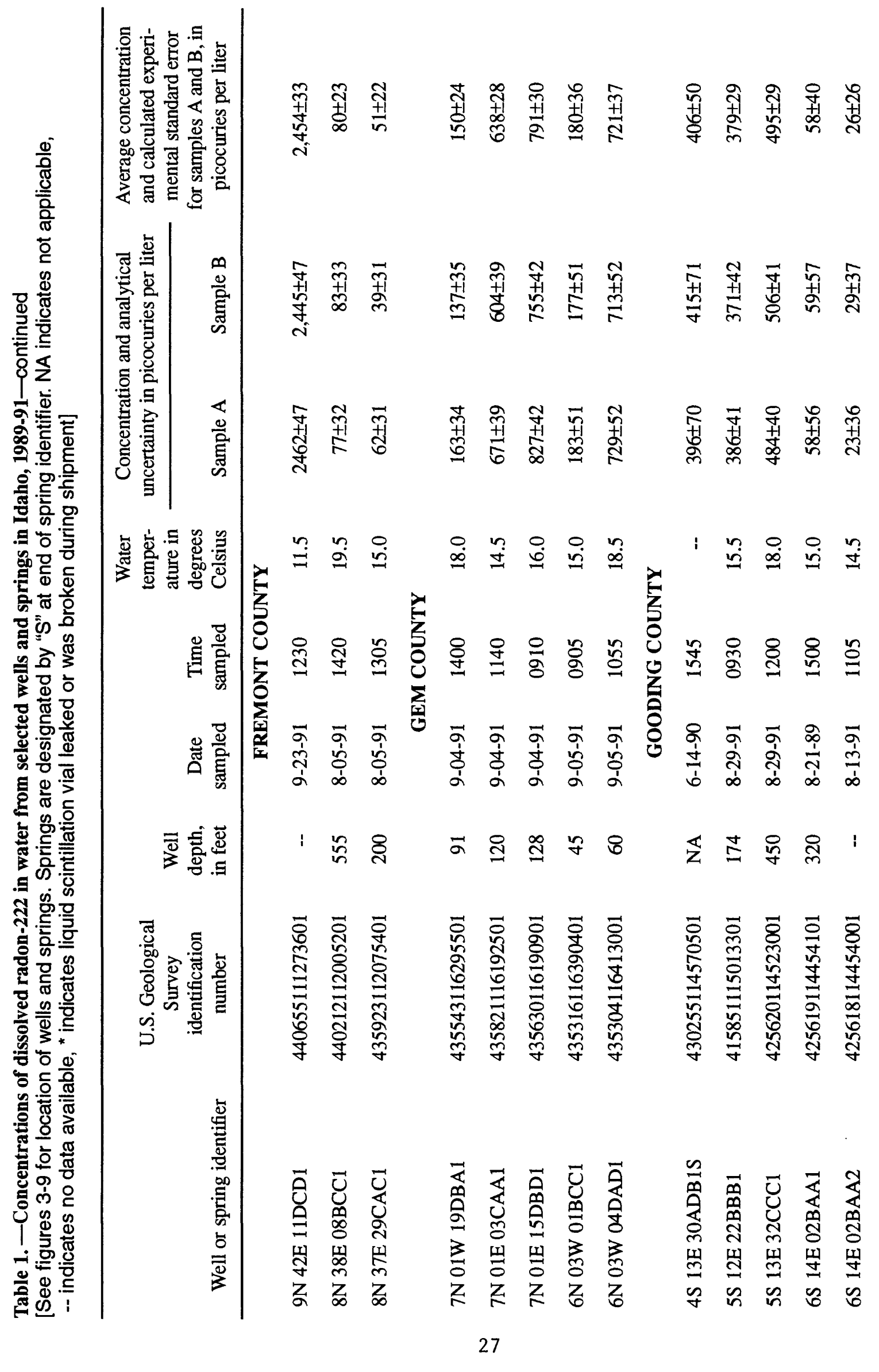




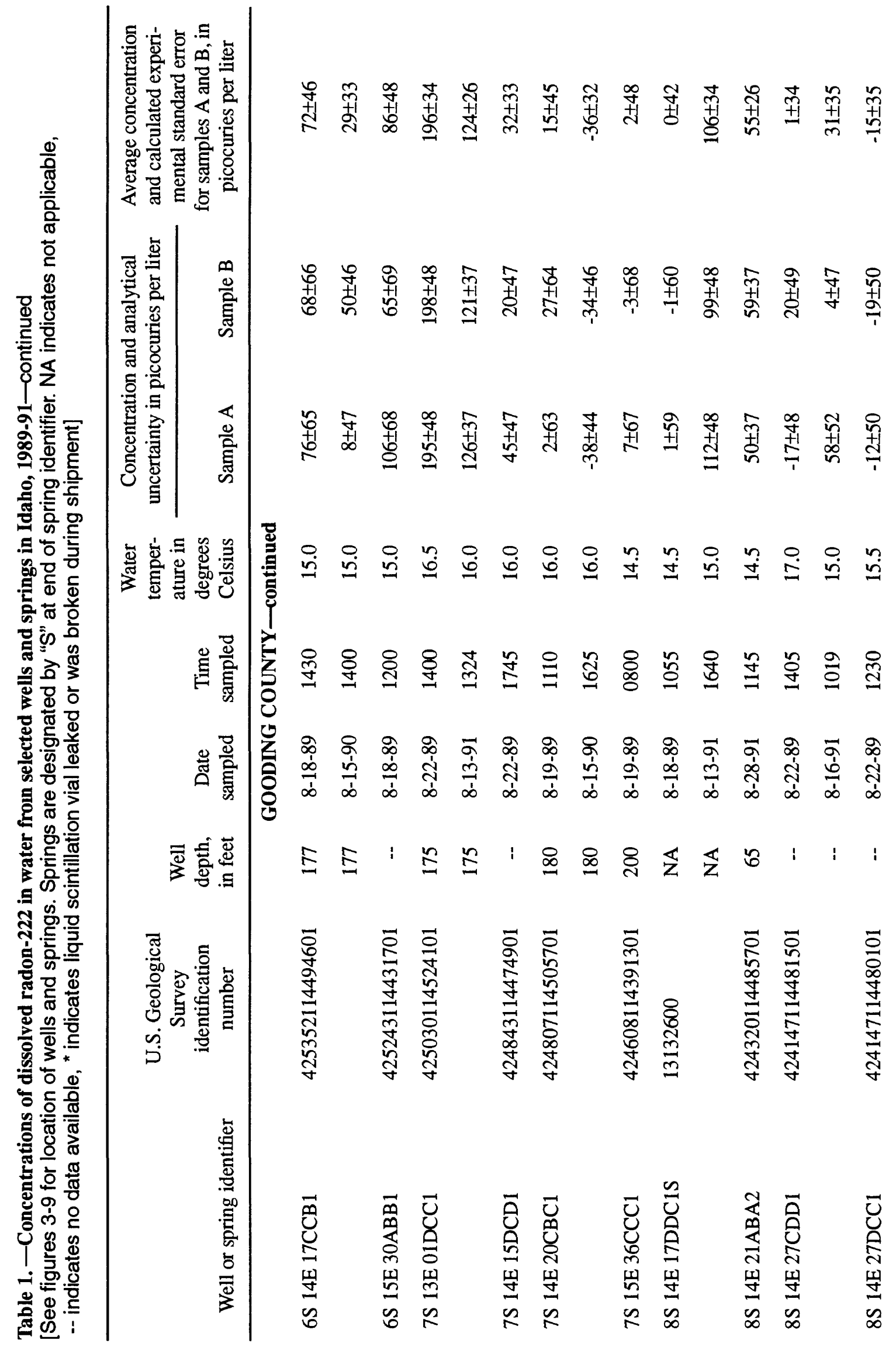




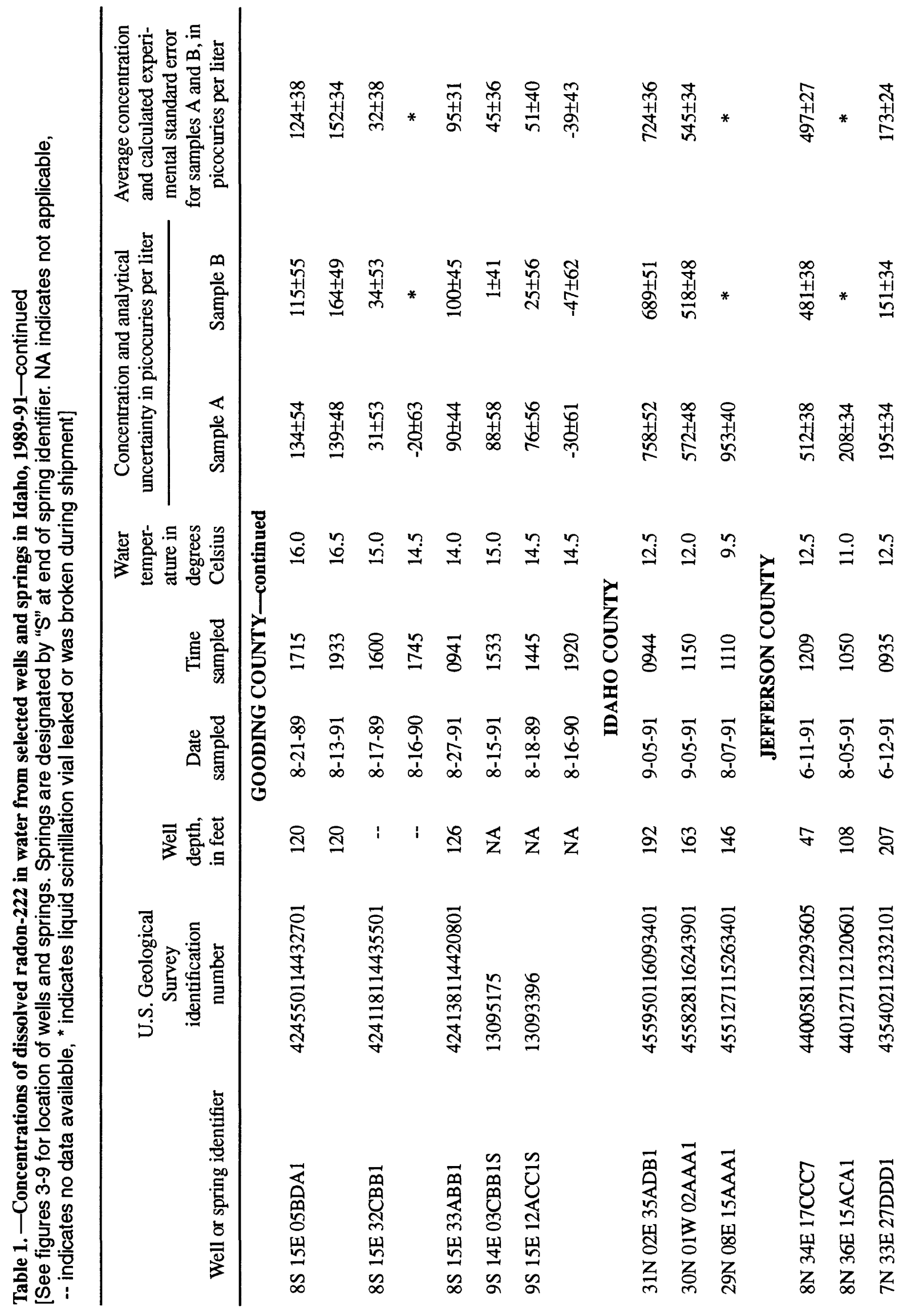




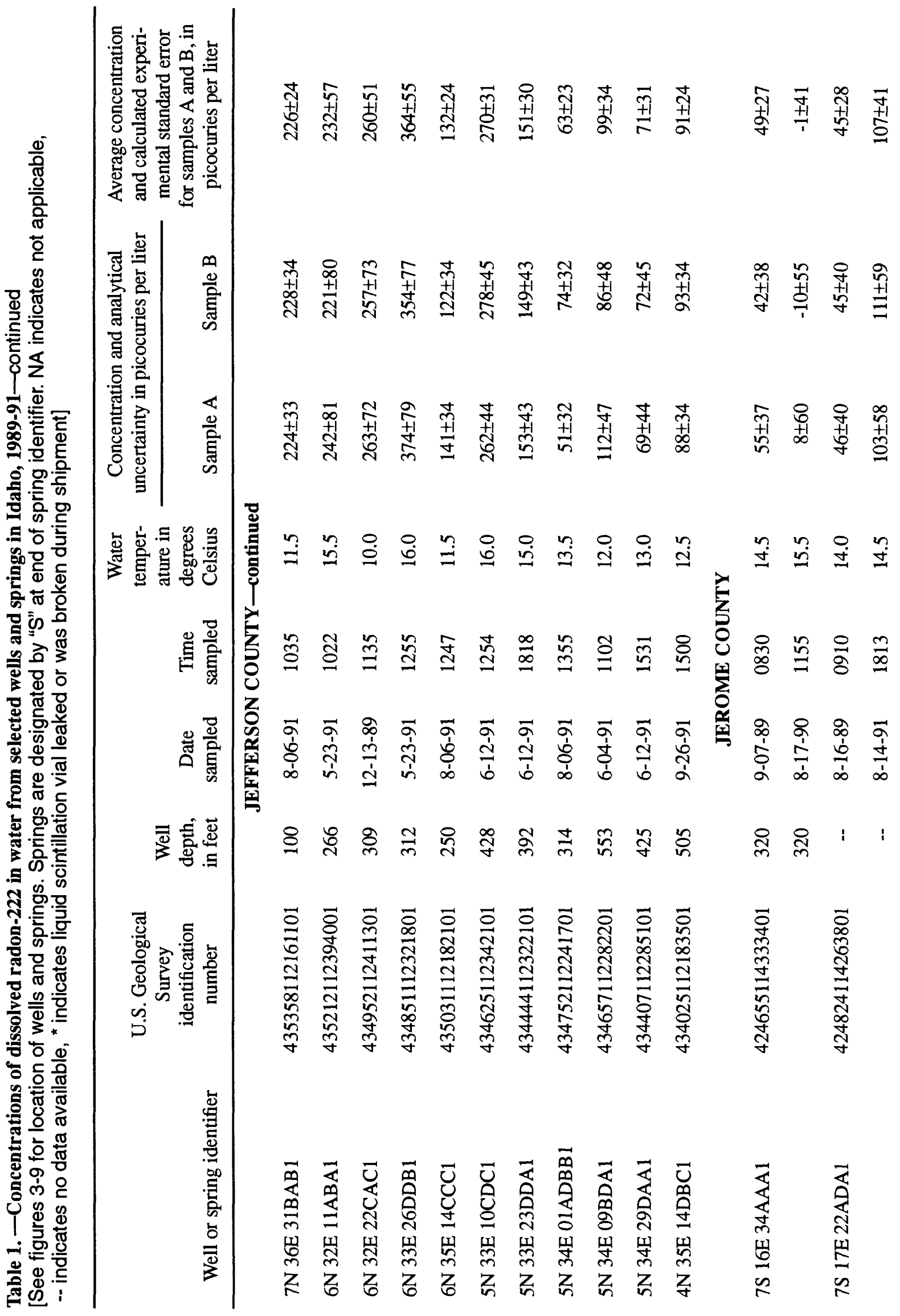




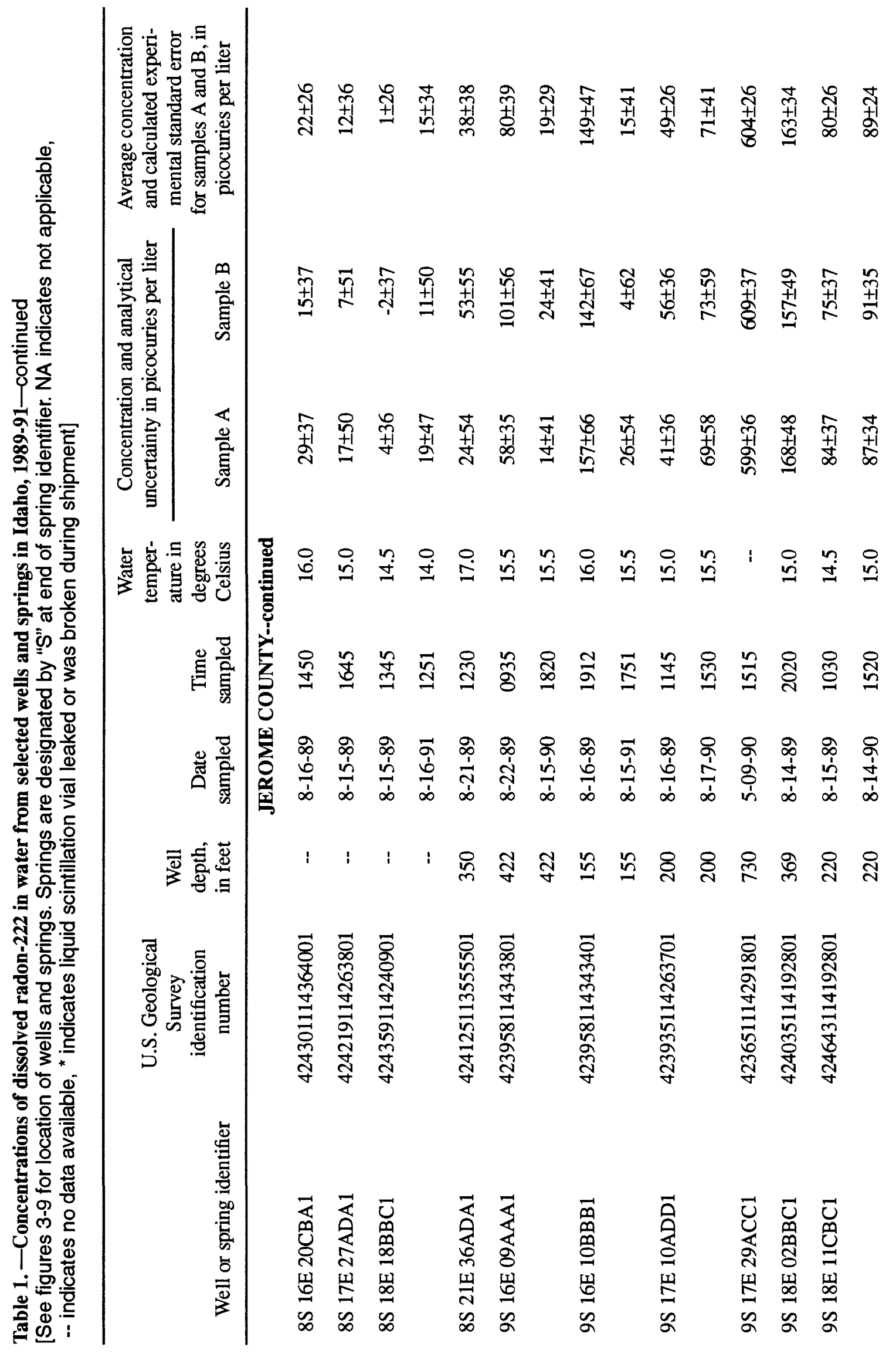




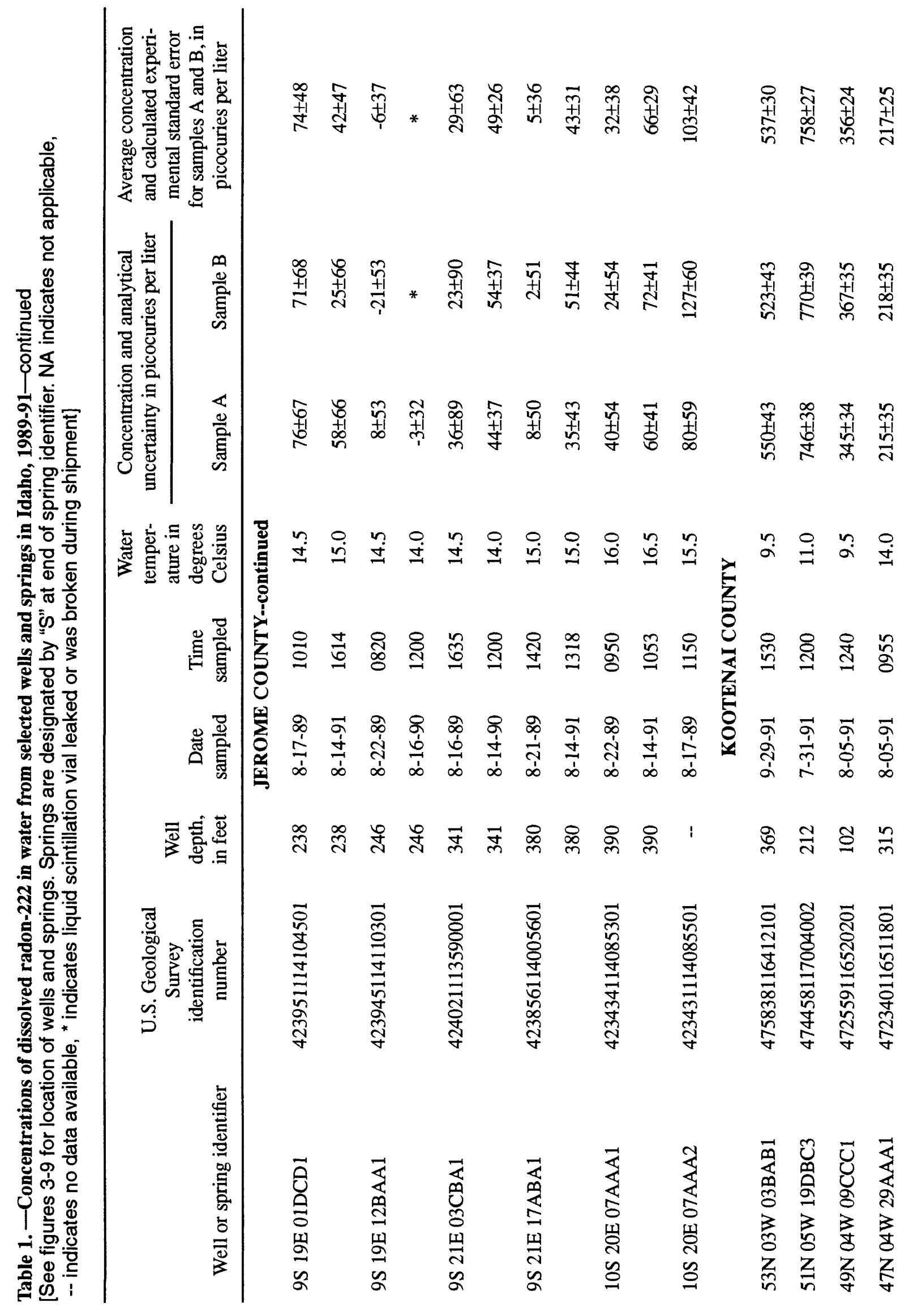




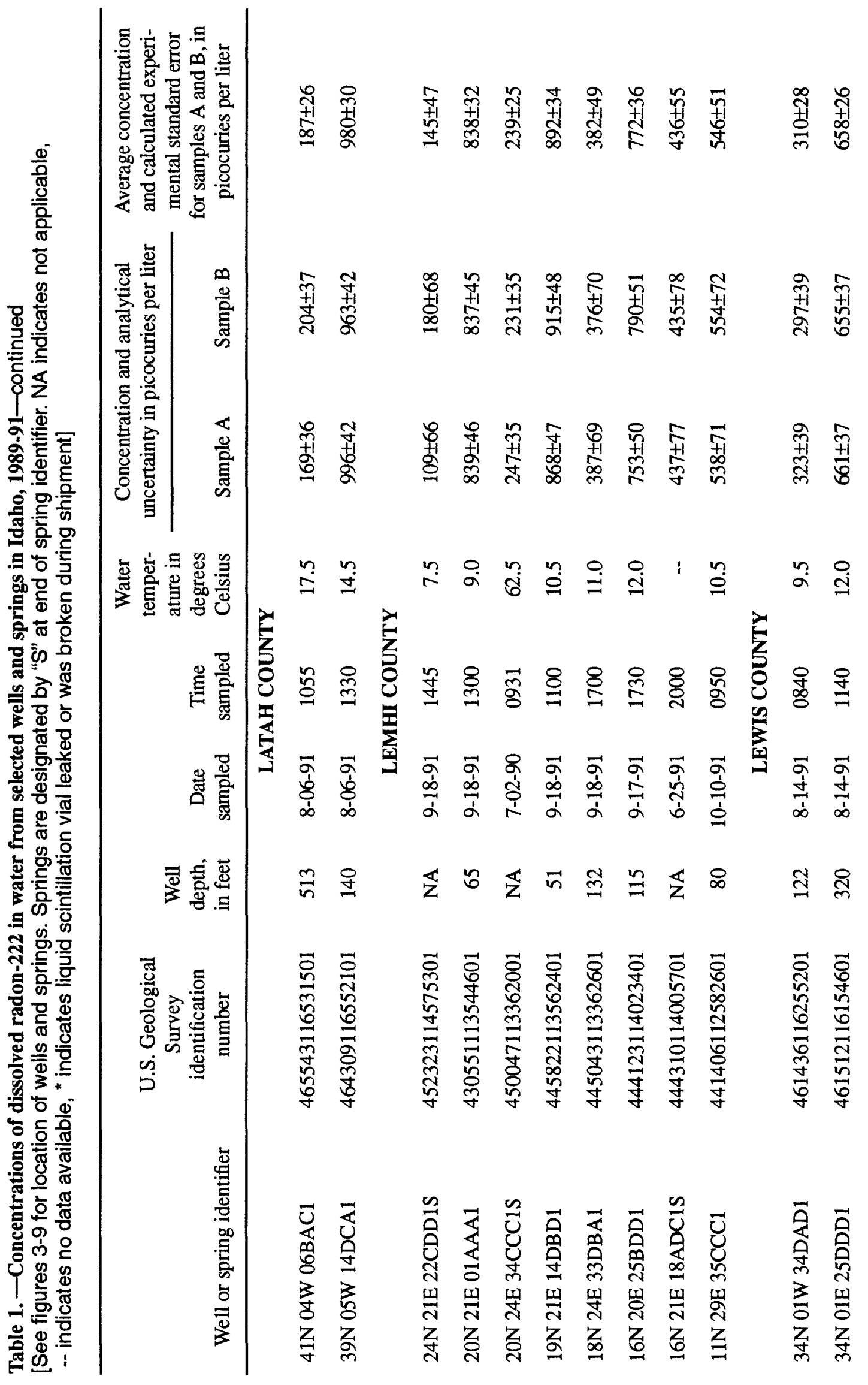




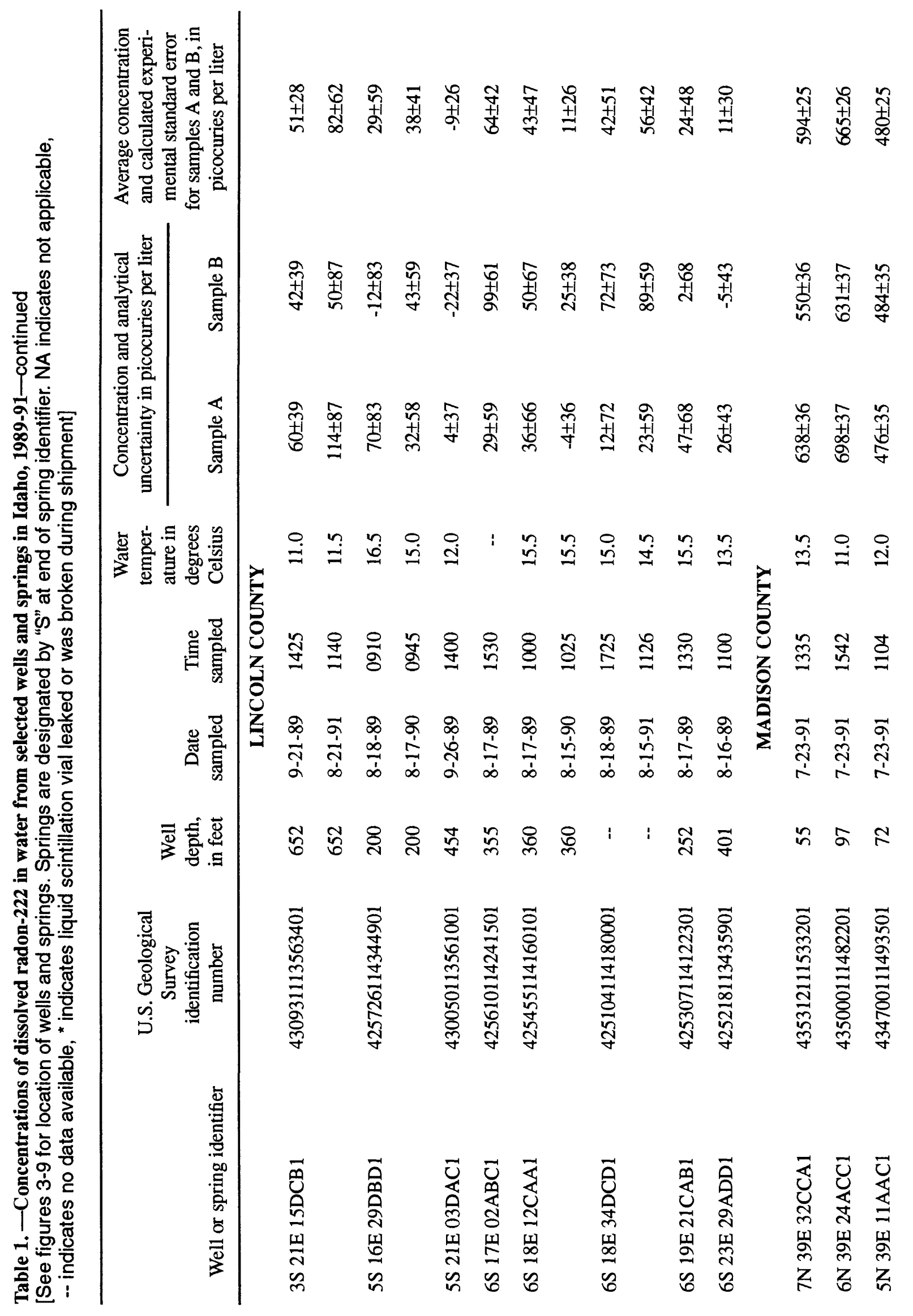




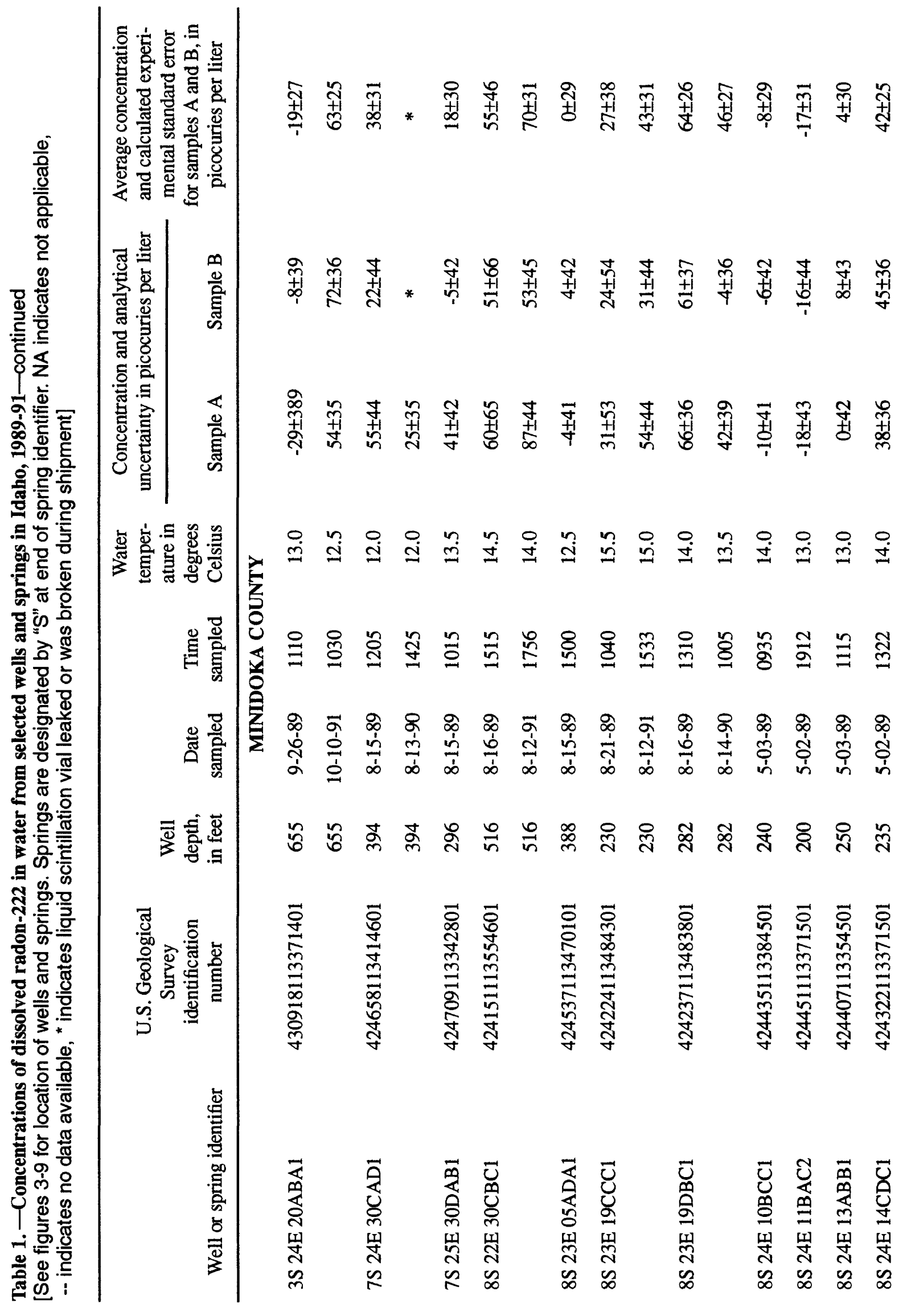




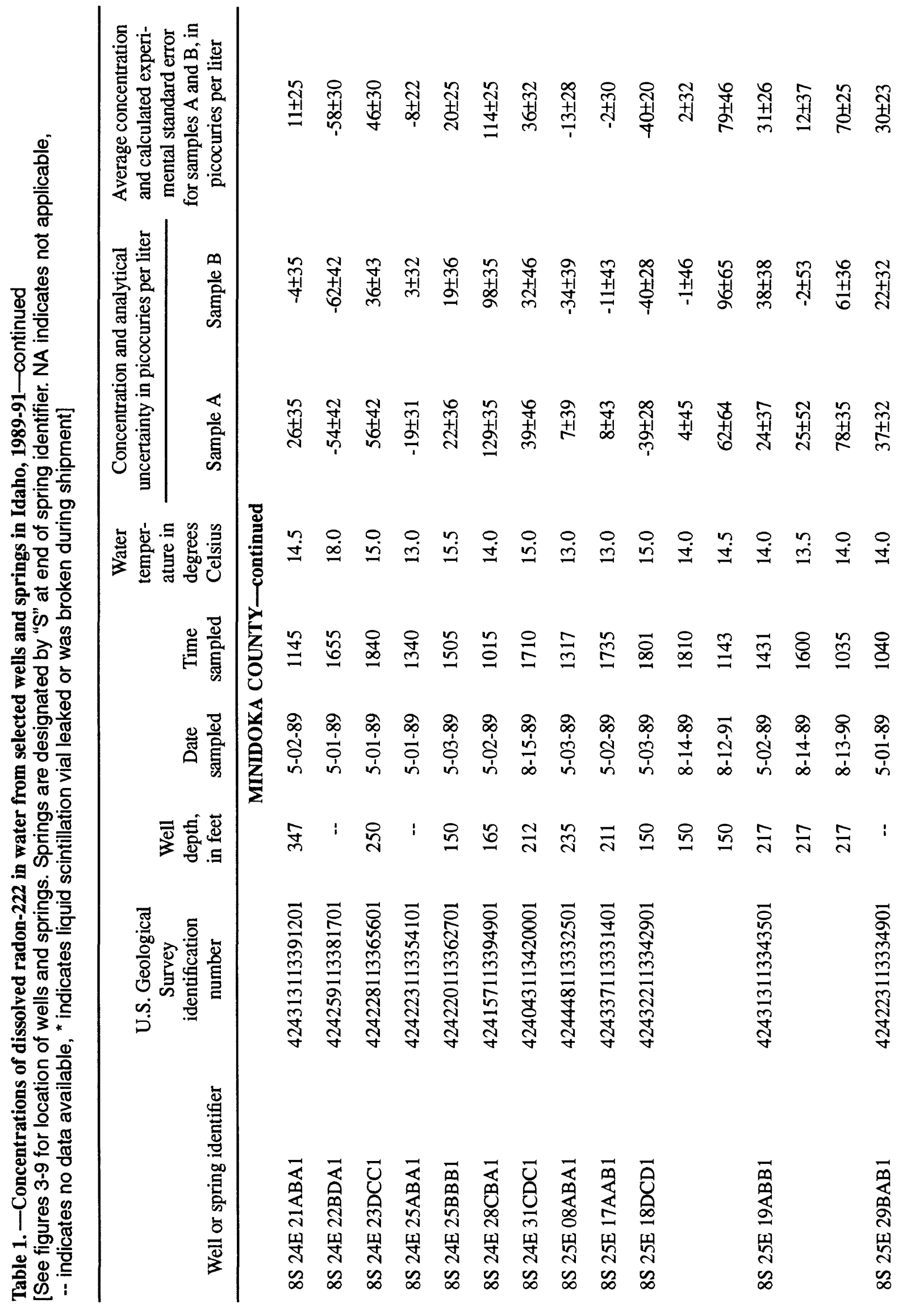




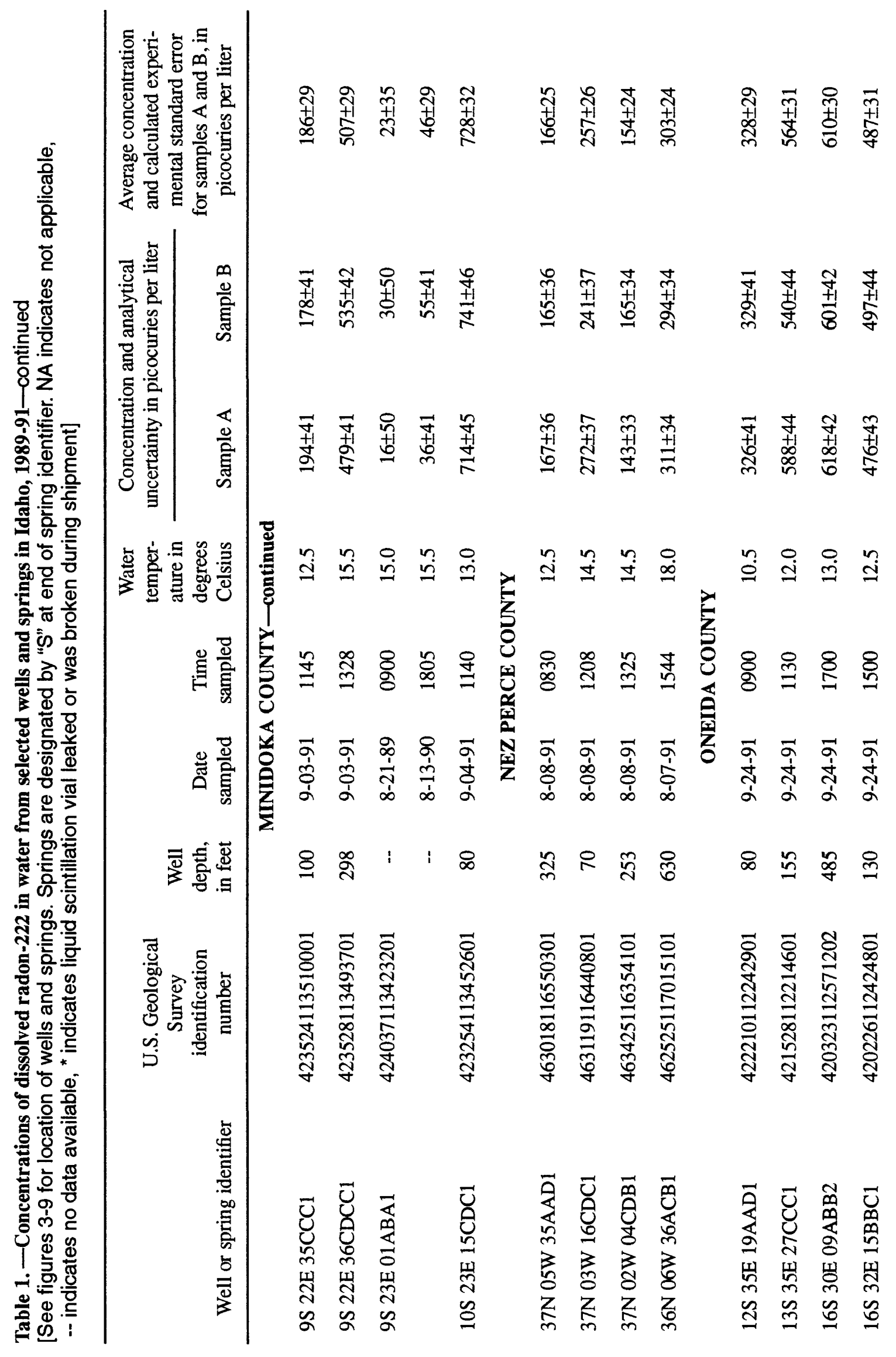




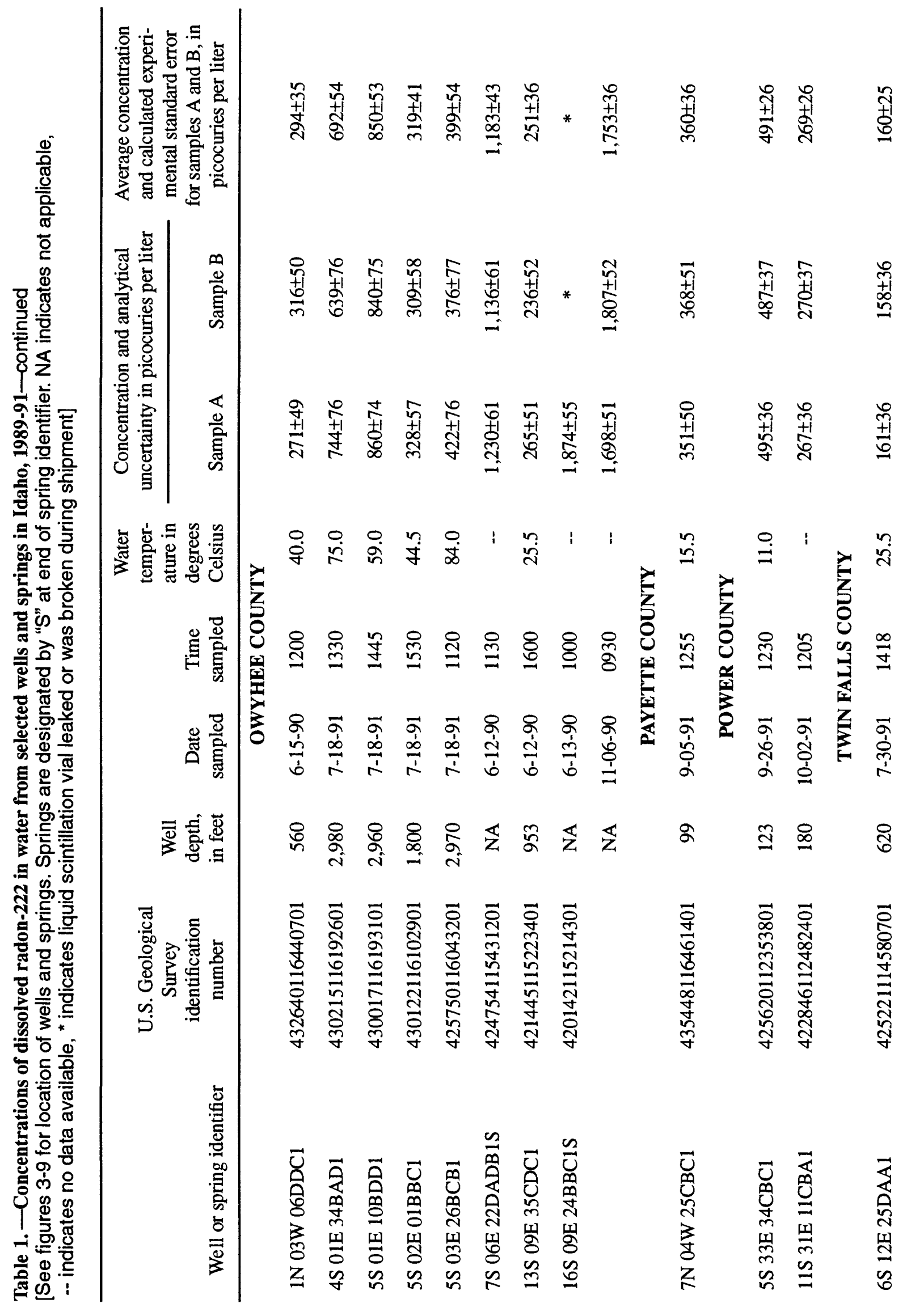




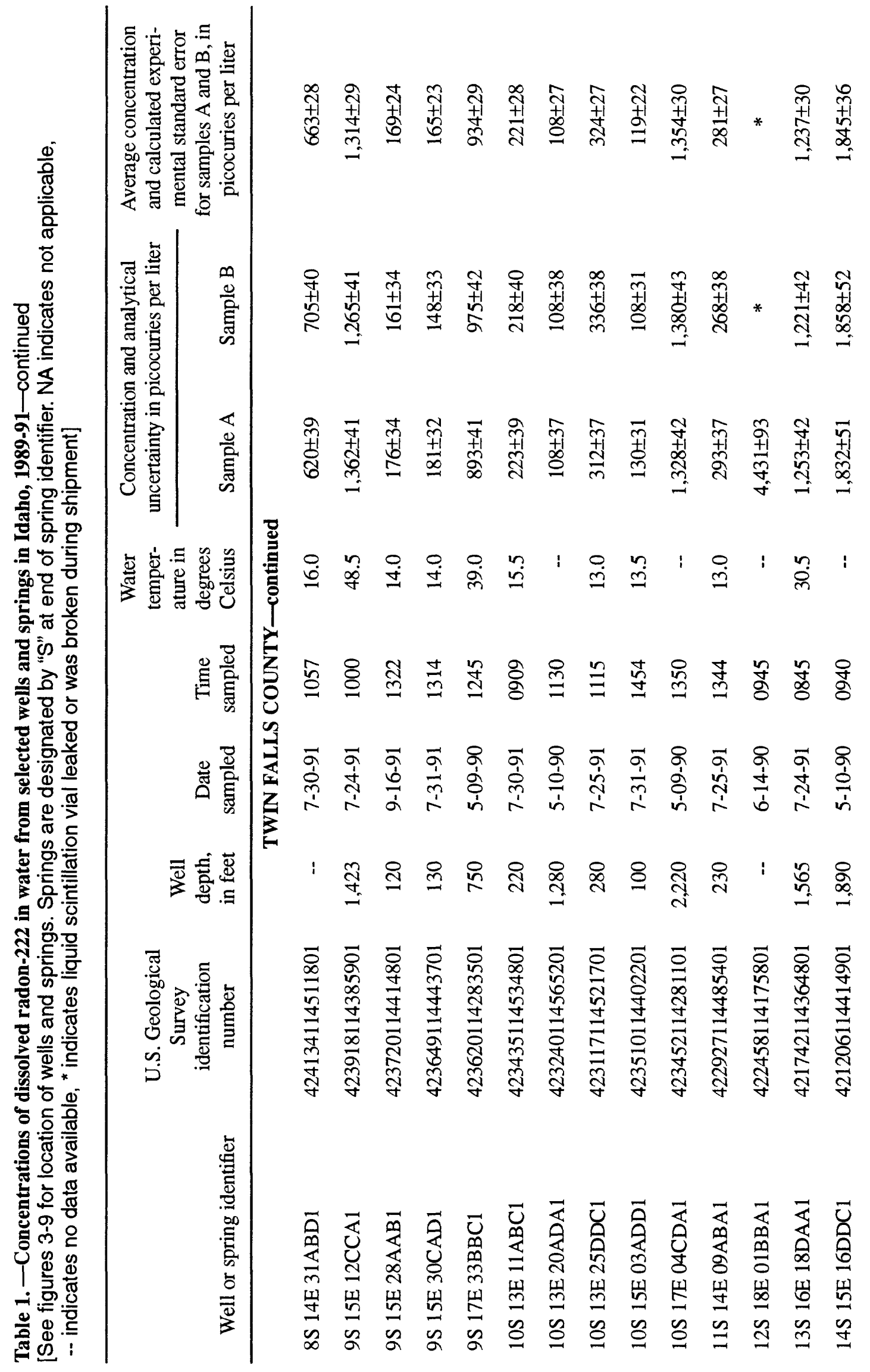




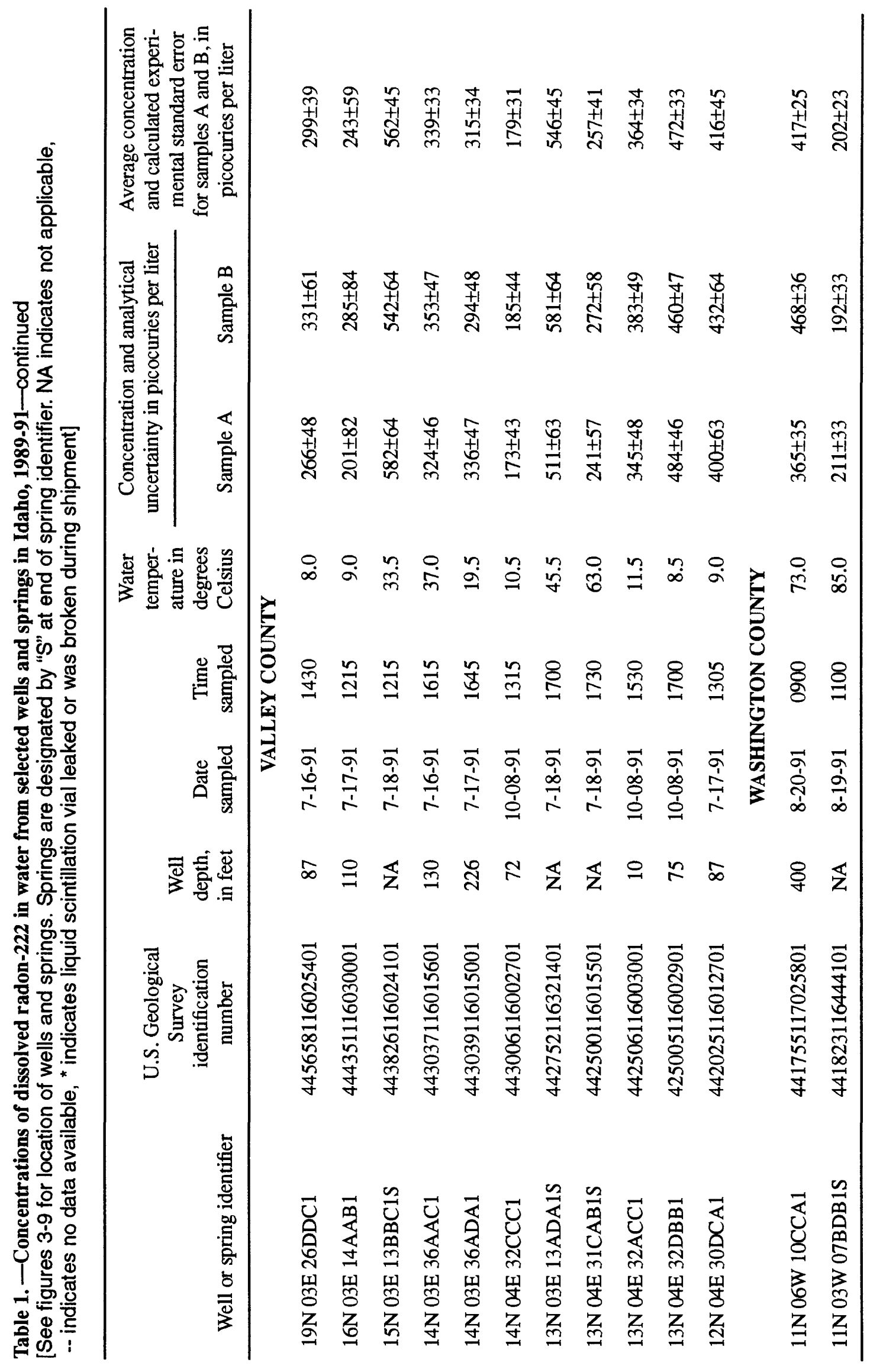

